Willem Faes*, Steven Lecompte, Zaaquib Yunus Ahmed, Johan Van Bael, Robbe Salenbien, Kim Verbeken and Michel De Paepe

\title{
Corrosion and corrosion prevention in heat exchangers
}

https://doi.org/10.1515/corrrev-2018-0054

Received June 22, 2018; accepted December 13, 2018

Abstract: In many industries and processes, heat exchangers are of vital importance as they are used to transfer heat from one fluid to another. These fluids can be corrosive to heat exchangers, which are usually made of metallic materials. This paper illustrates that corrosion is an important problem in the operation of heat exchangers in many environments, for which no straightforward answer exists. Corrosion failures of heat exchangers are common, and corrosion often involves high maintenance or repair costs. In this review, an overview is given of what is known on corrosion in heat exchangers. The different types of corrosion encountered in heat exchangers and the susceptible places in the devices are discussed first. This is combined with an overview of failure analyses for each type of corrosion. Next, the effect of heat transfer on corrosion and the influence of corrosion on the thermohydraulic performances are discussed. Finally, the prevention and control of corrosion is tackled. Prevention goes from general design considerations and operation guidelines to the use of cathodic and anodic protection.

Keywords: corrosion; geothermal; heat exchangers; heat transfer.

\footnotetext{
*Corresponding author: Willem Faes, Department of Flow, Heat and Combustion Mechanics, Ghent University, Ghent, Belgium; and Flemish Institute of Technological Research (VITO), Mol, Belgium, e-mail: willem.faes@ugent.be

Steven Lecompte and Zaaquib Yunus Ahmed: Department of Flow, Heat and Combustion Mechanics, Ghent University, Ghent, Belgium Johan Van Bael and Robbe Salenbien: Flemish Institute of Technological Research (VITO), Mol, Belgium; and EnergyVille, Thor Park, Genk, Belgium Kim Verbeken: Department of Materials, Textiles and Chemical Engineering, Ghent University, Ghent, Belgium Michel De Paepe: Department of Flow, Heat and Combustion Mechanics, Ghent University, Ghent, Belgium; and Flanders Make, Core Lab UGent-EEDT, www.flandersmake.be, Lommel, Belgium
}

\section{Introduction}

Heat exchangers are devices used to transfer thermal energy over a heat transfer surface from one fluid to a second fluid at a lower temperature (Kakaç et al., 2012). Several types of heat exchangers exist, but the most common types (the focus of this paper) are shell-and-tube heat exchangers and plate heat exchangers.

In a shell-and-tube heat exchanger, a number of tubes are mounted in a cylindrical shell, parallel to the axis of the shell (Kakaç et al., 2012). Typically, several vertical plates, baffles, are inserted in the shell to redirect the flow over the tubes and to improve the heat transfer. A schematic representation is given in Figure 1, where a cold fluid flows through the tubes and a hot fluid flows through the shell.

Plate heat exchangers consist of a number of thin plates, mounted behind each other in a frame (Kakaç et al., 2012). A gasket is placed between two adjacent plates to determine the flow path and to prevent the fluid from leaking to the environment. The plates are typically corrugated to improve the heat transfer. The working principle is illustrated in Figure 2.

Heat exchangers play a key role in the operation of various industrial processes like the oil and gas industry, the chemical and pharmaceutical industry, petroleum refining, and the pulp and paper industry. In each of these industries, the heat exchanger can be subject to a variety of environments. Some of them are known to be aggressive, while others are often not considered to be corrosive. It was calculated in 2001 that the direct cost of all types of corrosion in the United States amounts annually to $\$ 276$ billion or 3.1\% of the gross domestic product of the country (Koch et al., 2002). Of these costs, $\$ 17.6$ billion are allocated to production and manufacturing businesses, under which the aforementioned industries are categorised. For electrical power generation, in which heat exchangers are also frequently used, the annual corrosion cost is estimated in the same study at $\$ 6.9$ billion. In a more recent study by NACE International (2016), it was calculated that the annual global cost of corrosion amounts to $\$ 2.5$ trillion.

According to other sources (Electric Power Research Institute, 2001; Syrett \& Gorman, 2003; Roberge, 2008), 


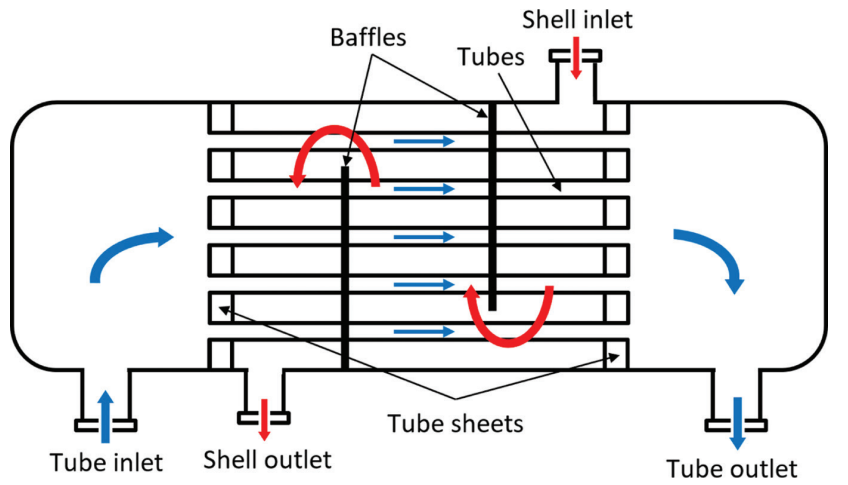

Figure 1: Schematic representation of a shell-and-tube heat exchanger.

the total cost of corrosion for the electrical power industry was $\$ 15.4$ billion in the United States in 1998. This amount is split into categories, where corrosion of heat exchangers takes up 5.55\% or $\$ 855$ million annually. These high losses are a combination of direct and indirect costs caused by corrosion and can be attributed to several economic consequences (Davis, 2000), as follows:

- Replacement of corroded equipment;

- Oversizing to take possible corrosion into account;

- Preventive maintenance;

- Shutdown of equipment;

- Loss of efficiency (e.g. when corrosion products decrease the heat transfer rate of the heat exchanger);

- Loss of a product (e.g. through leakages or contamination of a product).

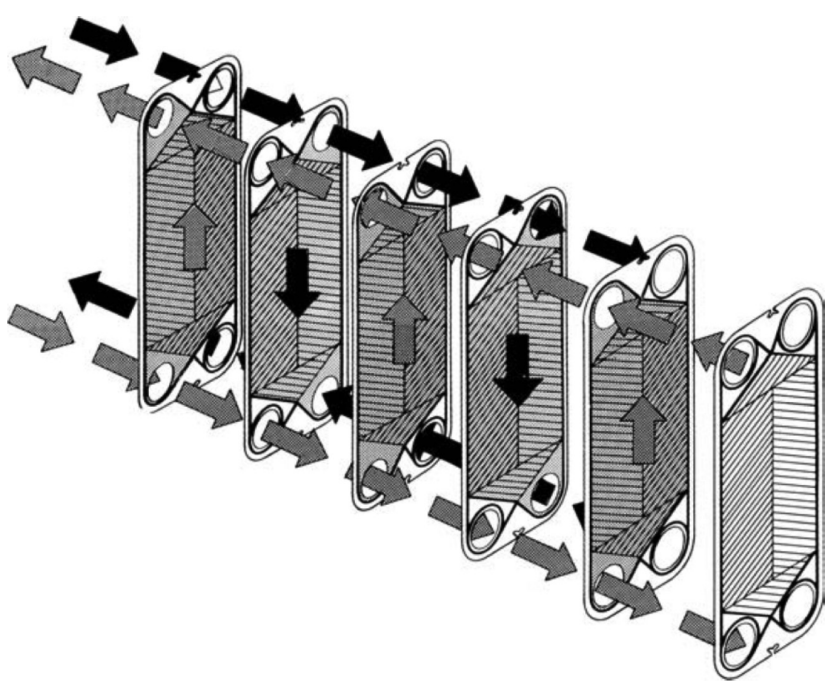

Figure 2: Plate heat exchanger with indicated flow paths. Republished with permission of Taylor \& Francis Group LLC, from Kakaç et al. (2012); permission conveyed through Copyright Clearance Center, Inc.
In addition to these economic issues, Davis (2000) also gave some examples of social consequences:

- Safety (e.g. risk for explosions);

- Health (e.g. escaping of a poisonous product from a corroded heat exchanger);

- Depletion of natural resources;

- Visually unpleasant appearance;

- Environmental contamination.

That a failing heat exchanger can pose a potential safety threat was illustrated by Collier (1983). According to the author, explosion of boilers (a thermal system analogous to a shell-and-tube heat exchanger) used in American steamboats occurred at least 233 times between 1816 and 1848, which in total caused the death of 2560 passengers and left 2100 others injured. One major accident was the explosion of the Sultana steamboat on the Mississippi River in 1865, resulting in $>1250$ deaths (Yager, 1976). Jennings (2015) stated that the boiler in this steamboat was made from wrought iron that most likely contained inclusions and imperfections resulting from the production techniques from that period. These are sites where corrosion could initiate, and therefore Jennings claimed that possibly corrosion at these sites was the root of the tragic incident. The explosion of land-based boilers was a common problem as well. In his publication, Collier (1983) also emphasised on the fact that between 1890 and 1904, 5000 incidents of such explosions were reported by one insurance company.

Although the knowledge about heat exchangers and the existing production techniques have drastically improved, accidents caused by corrosion still occur. Two more recent failures of heat exchangers, illustrating the potentially catastrophic consequences, were reported on an offshore gas production platform in 2006 and in a refinery plant in 2010.

In the first incident, a shell-and-tube heat exchanger, made from carbon steel clad with titanium, was used to cool hydrocarbon gas with seawater (Health and Safety Executive, 2006; Parrott, 2014). Galvanic corrosion between the carbon steel and titanium cladding caused the escape of the gas into the seawater, overpressuring the shell. The shell and the tubes got torn from the tube sheet and the escaping gas exploded. Luckily, there were only two minor injuries. The second incident was a carbon steel shell-and-tube heat exchanger, but with a stainless-steel type 316 liner [U.S. Chemical Safety and Hazard Investigation Board (CSB), 2010; Marsh, 2016]. The shell ruptured at the weld seams, releasing the hot hydrogen and naptha. The mixture autoignited, resulting in seven fatalities. The root cause of the accident was determined to be hightemperature hydrogen attack (HTHA) of the carbon steel. 
Both galvanic corrosion and hydrogen damage in heat exchangers will be discussed later.

In the literature, various failure analyses can be found where heat exchangers suffered corrosion. According to the authors' knowledge, no paper gives an overview or describes the particularities of the corrosion processes occurring in heat exchangers. Therefore, this study gives a non-exhaustive overview of the failures, to show which types of corrosion are common and which places are susceptible. As the research on either the influence of heat transfer on corrosion, or vice versa, is scattered, this is described in a next section. Based on recommendations given in the failure analyses and heat exchanger design handbooks, guidelines are provided on how to prevent corrosion in heat exchangers. Additionally, two more specialised corrosion protection techniques, cathodic and anodic protection, are discussed. A great deal of the information about these methods was found in the patent literature.

The many failures discussed in this paper demonstrate that corrosion is a challenging problem in the operation of heat exchangers. Most failures are caused by localised forms of corrosion, such as pitting or stress corrosion. To prevent this, careful material selection, design phase, and operation are absolute prerequisites to guarantee a long lifetime of the heat exchanger. Electrochemical techniques exist to limit corrosion of heat transfer surfaces (cathodic and anodic protection). Their application in heat exchangers is, however, not straightforward.

\section{Types of corrosion encountered in heat exchangers}

Corrosion is a term used to describe the (unwanted) degradation of a metal when exposed to an environment, due to interaction with this environment. Most of the examples discussed below involve aqueous environments. The corroding metal in the liquid is called the anode, and the metal ions go into solution following the anodic oxidation reaction. Corrosion is only possible if the electrons resulting from this reaction are consumed by a cathodic reaction (e.g. the reduction of dissolved oxygen). An electrically conductive path must exist between the two locations for the electrons to pass (Edwards, 2013). This corrosion process is illustrated in Figure 3. Many types of corrosion are possible, depending on the material, the environment, and the working conditions (Roberge, 2000). In the next sections, the most prevalent forms encountered in heat exchangers are discussed and several examples of failures of heat exchangers, caused by corrosion, are presented.

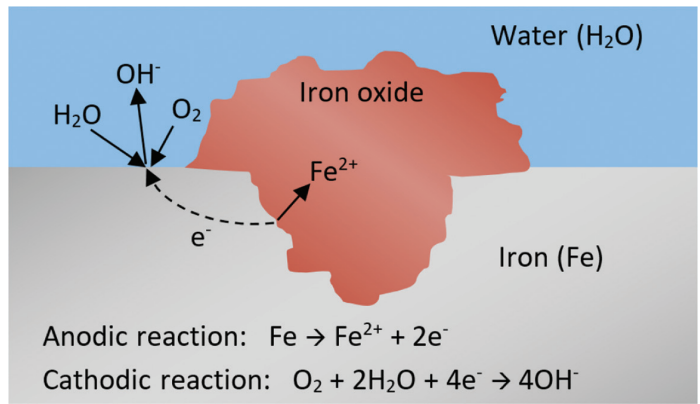

Figure 3: Schematic representation of the corrosion process of ironbased alloys in aqueous solutions.

\subsection{Uniform corrosion}

When corrosion is homogeneously spread over the entire heat transfer surface, the term "uniform corrosion" is used. Uniform corrosion is usually easy to detect visually. The thinning of the tube or plate increases the stresses in the metal, which might eventually lead to failure (Wang et al., 2007). One strategy to avoid this type of corrosion is by selecting a material that passivates in the specific environment. Alternatively, by doing exposure tests prior to the use of the heat exchanger, the corrosion rate can be determined (expressed, e.g. in $\mathrm{mm} /$ year), which allows designing the heat exchanger with an increased wall thickness (Revie \& Uhlig, 2008).

This does not imply that uniform corrosion does not pose any problems. For example, different uniform corrosion rates in different parts of the exchanger are problematic for overhauling. In the case described by Xie et al. (2015), the carbon steel tubes of a vertical shell-and-tube heat exchanger, used to cool a stripper overhead vapour, had to be replaced after only 2.5 years of service (Xie et al., 2015). Around the tubes, cooling water flowed, which cooled the process vapour inside the tubes. Brown and reddish rust was found on both internal and external surfaces, and severe wall losses ( $>70 \%$ for 159 of the 1410 tubes) were detected. Figure 4 shows a cross section of different tubes. Signs of corrosion can be seen on both external and internal surfaces, and the difference in wall thickness can clearly be observed. The authors discovered that the corrosion was most severe just underneath the top tube sheet. This was explained by the accumulation of non-condensable gases at the top of the shell area, causing the concentration of corrosive elements (e.g. chlorides) in the water on the hot tube surfaces at the vapourliquid interface.

The uniform corrosion was more severe at the cooling water side than at the internal surface of the tubes. However, uniform corrosion was not the only type of 


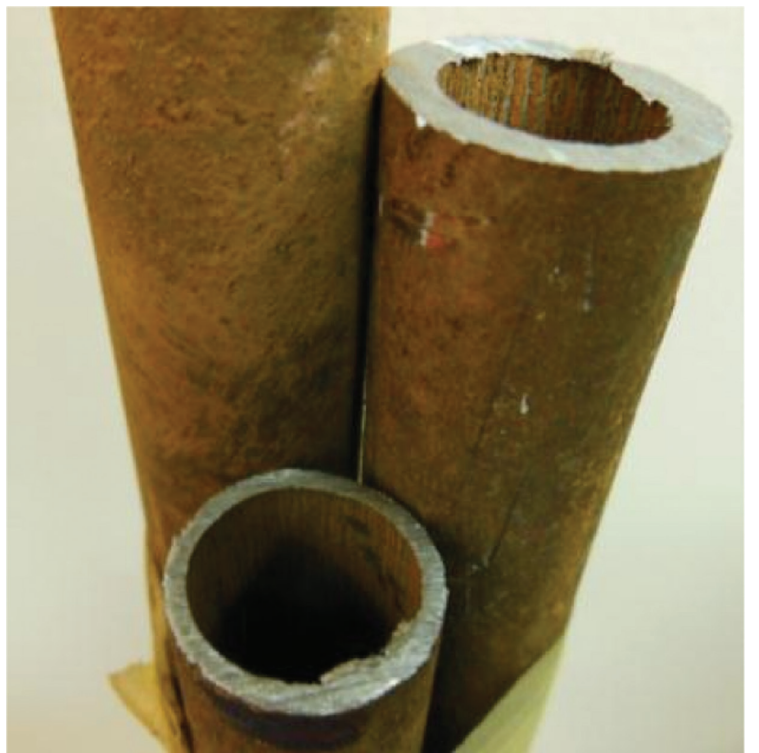

Figure 4: Section of the tube with severe uniform corrosion and wall thickness reduction.

Reprinted with permission from NACE International, from Xie et al. (2015).

corrosion observed inside the tubes; localised forms of corrosion, like pitting corrosion (Section 2.2) and erosion corrosion (Section 2.5), were also detected.

The recommendations made by the authors were adaptation of the water discharge to avoid the accumulation of non-condensable gases and a different type of steel.

One other example of a failed shell-and-tube heat exchanger for which uniform corrosion was one of the main causes of failure is an oil cooler described by Eich (2012). No cases of plate heat exchangers that failed because of uniform corrosion could be found in the literature. This low number of incidents, in comparison to the next types of corrosion, can possibly be attributed to the fact that it is, in general, easy to account for design or material selection and to detect uniform corrosion (Roberge, 2008). In contrast to uniform corrosion, the next types of corrosion do not include an appreciable weight loss of the metal. The damage to the material is localised and not always easy to monitor (Revie \& Uhlig, 2008).

\subsection{Pitting corrosion}

The first form of localised corrosion is pitting corrosion. Metals covered with a protective film (either reaction products resulting from spontaneous interactions with the environment or created by a surface treatment such as the application of a coating) are often susceptible to pitting (Revie \& Uhlig, 2008). At mechanical defects of this protective layer, pits are initiated, and when these grow sufficiently, they might perforate the heat transfer surface. The initiation of pitting is influenced by metallurgical and structural factors, environmental factors, polarisation phenomena, and the presence of corrosion products. For stainless steel, high chloride content, high temperatures, and low $\mathrm{pH}$ are promoters of pitting corrosion. Some metals often used in the construction of heat exchangers whose protective film might locally break down, and as such initiate pitting, are other passivating metals such as aluminium, nickel, titanium, and their alloys (Kuppan, 2000).

The tendency of a stainless steel to be susceptible to pitting corrosion can be predicted with the pitting resistance equivalent number (PREN). This number can be calculated with Eq. (1) based on the mass fraction (in percentage) of chromium (Cr), molybdenum (Mo), tungsten $(\mathrm{W})$, and nitrogen $(\mathrm{N})$ in the alloy (Roberge, 2000). The common type of stainless steel, type 304, has a PREN of 19 , while highly alloyed types of stainless steel can go to a PREN of $>50$. For seawater applications at $20^{\circ} \mathrm{C}$, a PREN of at least 32 is advised (Veldkamp et al., 2016).

$$
\mathrm{PREN}=\mathrm{Cr}+3.3 \times(\mathrm{Mo}+0.5 \mathrm{~W})+16 \mathrm{~N} \text {. }
$$

The shell-and-tube heat exchanger discussed in the failure analysis by Julian et al. (2015) was used in a geothermal plant. Deep pits, of which some perforated the tube, were discovered in the middle tubes (the lower and upper tubes were free of pits). Figure 5 shows a cross section of a part of the tube where pits are present. It was found that the

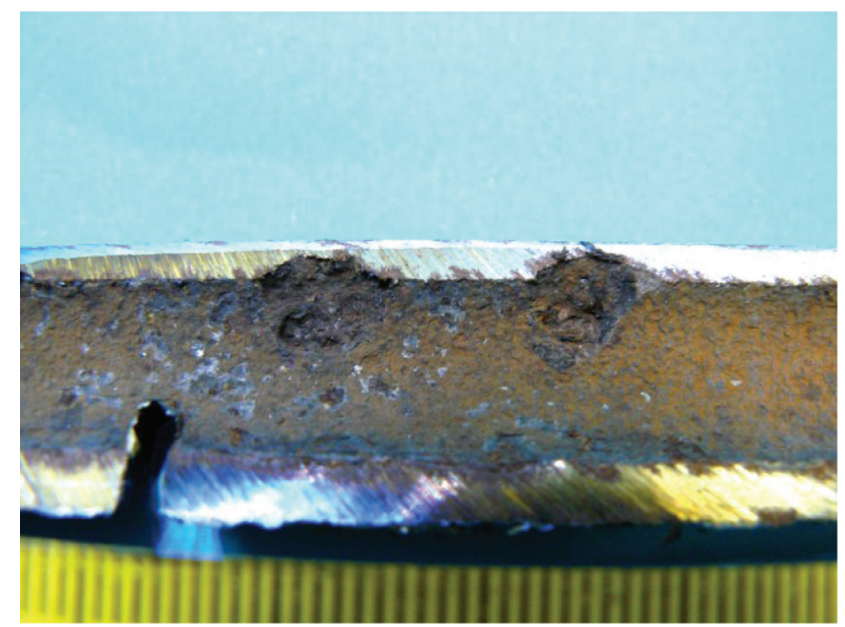

Figure 5: Cross section of a tube damaged by pitting corrosion. Reprinted from Julian et al. (2015), with permission from International Geothermal Association. 
lower and upper tubes were preferentially filled with brine and steam, respectively, while the middle tubes received a mixture of condensing steam and brine. These conditions caused an increasing concentration of acid gases like $\mathrm{CO}_{2}$ and $\mathrm{H}_{2} \mathrm{~S}$ in the condensing water, making it even more acidic. This locally high acidity was suggested as the reason for the rapid development of pits in only one row of tubes. Also, elemental arsenic, which precipitated from the brine, was observed in the pits, which might have enhanced corrosion by galvanic effects (galvanic corrosion is discussed in Section 2.7).

An example of a plate heat exchanger that failed due to pitting is described by Deen et al. (2010). In their study, the failure of a heat exchanger with plates constructed with type $316 \mathrm{~L}$ stainless-steel plates $(\mathrm{PREN} \approx 24.2)$ is investigated. The device was used in the cooling loop of textile mill. A 316L stainless steel was originally chosen for its corrosion-resistant properties; however, when the heat exchanger was opened for maintenance after $2000 \mathrm{~h}$ of operation, it was observed that several of the plates were perforated by pits. An example of a failed plate can be seen in Figure 6. The authors concluded that a local breakdown of the passive oxide film occurred, which was caused by high chloride contents in the cooling water.

Additional examples of failure analyses of shell-andtube heat exchangers where pitting was one of the main modes of corrosion-related failure can be found in the following references: Xie et al. (2015), Ghayad et al. (2015), Qiankun et al. (2017), Sanders and Iwand (2013), Ifezue and Tobins (2015), Zheng et al. (2014), Song et al. (2013), and Abouswa et al. (2007). Two papers in which pitting corrosion in plate heat exchangers was observed are described by Crum et al. (2007) and Turissini et al. (1997). The main corrosion process in this last case was, however, crevice corrosion, which is a type of corrosion with some similarity to pitting corrosion and will be discussed in the next section.

\subsection{Crevice corrosion}

Crevice corrosion is another intense and dangerous form of localised corrosion, caused by a local environment different from the bulk environment. In crevices or shielded areas with stagnant liquid, a depletion of oxygen can occur. The initiation of crevice corrosion is influenced by this differential concentration of oxygen. The presence of chlorides can also cause the initiation of crevice corrosion. The rate of corrosion increases as the crevice narrows and the cathode area is increased (Roberge, 2000). In plate heat exchangers, such crevices are typically present at the gaskets (metal/non-metal contact), at the plate contact points, and under deposits.

The studies by Crum et al. (2007) and Cassagne et al. (2010) illustrate the difficulty of avoiding crevice corrosion in plate heat exchangers for seawater applications. In both studies, several metals are tested as plate material at elevated temperatures (up to $70^{\circ} \mathrm{C}$ ) with both laboratory tests and exposure to real seawater (with controlled chlorine concentrations, added to suppress marine life) in dummy heat exchangers. The metals tested were super-austenitic stainless steels, nickel-chromium-molybdenum alloys, and titanium. Almost all metals, even titanium, showed signs of crevice corrosion in the most severe conditions. Only the most recent Ni-Cr-Mo alloys, like alloy 686 [Unified Numbering System (UNS) N06686], could withstand the corrosive environment. An example of severe crevice corrosion at the gasket area of a plate made from alloy 31 (UNS N08031) is shown in Figure 7. More cases of crevice corrosion in plate heat exchangers were described by Turissini et al. (1997).

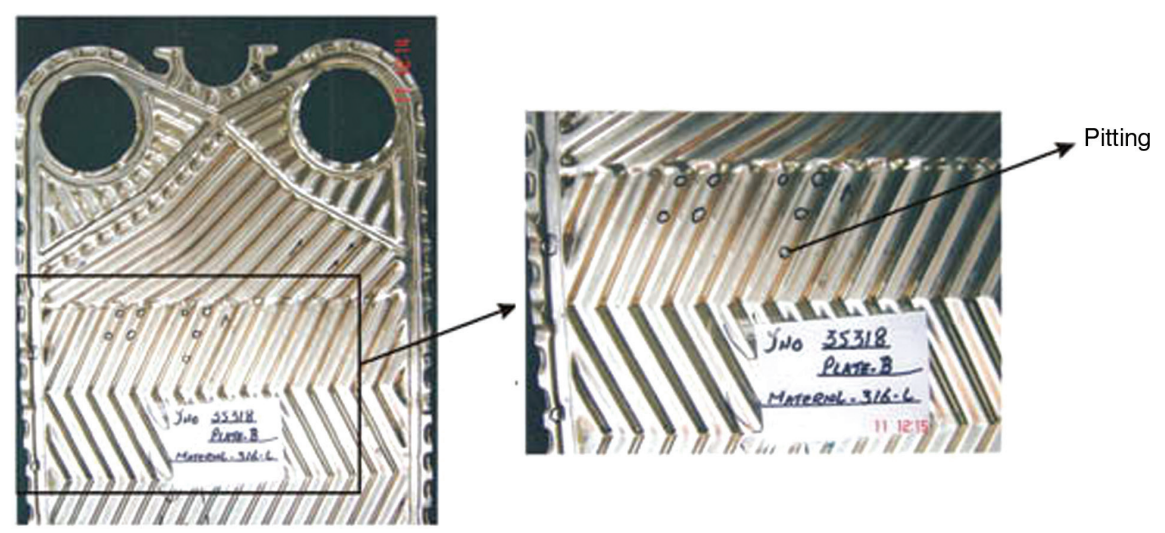

Figure 6: Pitting corrosion damage in a plate heat exchanger. Reprinted from Deen et al. (2010), with permission from Elsevier. 


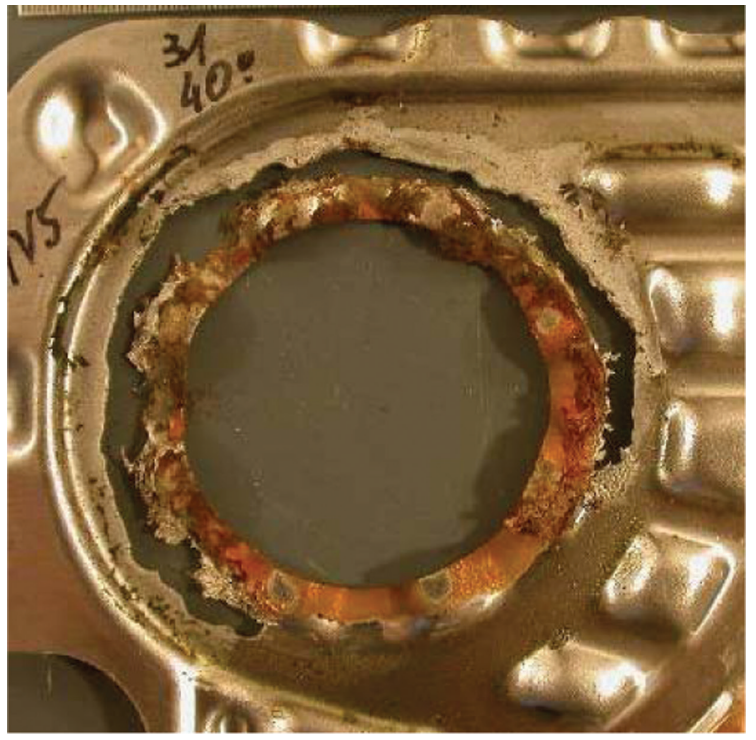

Figure 7: Crevice corrosion under the gasket of a plate heat exchanger.

Reprinted with permission from NACE International, from Cassagne et al. (2010).

In shell-and-tube heat exchangers, the critical areas for crevice corrosion are clearances between rolled tubes and tube sheets, open welds, and bolt holes. Also, complex geometric designs with sharp edges are prone to crevice corrosion (Kuppan, 2000). The investigations in the publications by Yang et al. (2012), Kaul et al. (1995), and Allahkaram et al. (2011) give some additional examples of failure analyses where crevice corrosion was found between the tube and the tube sheet. In the work of Allahkaram et al. (2011), crevice corrosion was also found in gaps between the tubes and the baffles. A last example is the study on oil coolers by Eich (2012) (already mentioned in the discussion of uniform corrosion), where crevice corrosion was detected on the tube sheet. The crevice was, however, not formed between the tube sheet and the tubes but between the tube sheet and a deflector in the head of the cooler.

\subsection{Stress corrosion}

When a corrosive environment is combined with mechanical stresses, the corrosion process is aggravated. A first type where corrosion and stress join forces is stress corrosion cracking (SCC). This corrosion mechanism involves a static tensile stress present in a susceptible metal in a corrosive environment, causing failure where the same structure would be able to endure the same stress in a non-corrosive environment. These stresses can be external, but also residual stresses, e.g. from welding or cold working (Roberge, 2000). In shell-and-tube heat exchangers, residual stresses are often found at tube-totube sheet expanded joints and U-bends (Kuppan, 2000). Residual stresses also often cause SCC in cold-rolled plate heat exchangers (Wang et al., 2007).

Walker (1990) mentioned that SCC can also be caused by corrosion products in a constricted or confined space. The volume of corrosion products is often larger than that of the base metal, causing a wedging action with high local stresses. Similar to this wedging is denting, which occurred in nuclear steam generators (Walker, 1990). Inconel tubes passed through carbon steel supports that corroded. The tubes were dented inwards because of an accumulation of corrosion products in the annulus between the tubes and the support.

A second kind of corrosion where stresses play a role is corrosion fatigue. This is characterised by a fluctuating load substantially below the yield point. The fatigue behaviour of metals is affected by corrosive media. Figure 8 illustrates the influence of corrosion on the fatigue behaviour with an S-N curve. It can be seen that failure occurs within fewer cycles for a given stress, and a fatigue limit is no longer observed (Revie \& Uhlig, 2008). Similar to SCC, corrosion fatigue is often initiated at various types of stress concentrations (Wang et al., 2007).

Tawancy (2009) analysed the failure of a shell-andtube heat exchanger used in an oil refinery. Leaks were detected in some bends after $48 \mathrm{~h}$ of starting the unit after a period of downtime. The conclusion of the author is that during the shutdown, polythionic acid was formed from sulphur-bearing deposits and condensed water vapour. This acid, in combination with internal stresses in the bend, induced the cracks in the metal (type 321 steel), shown in the photograph of Figure 9.

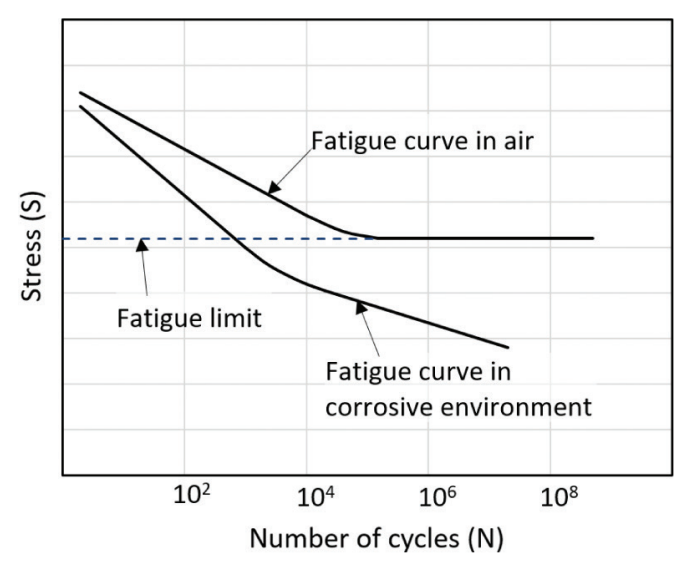

Figure 8: S-N curve illustrating the influence of corrosion on fatigue behaviour. 


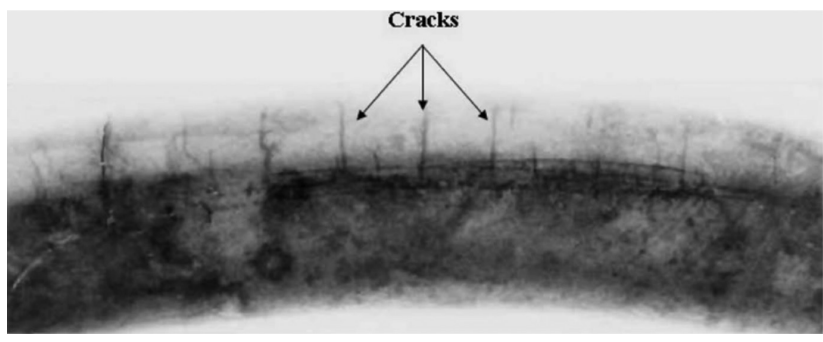

Figure 9: Stress corrosion cracks induced in a bend by polythionic acid.

Reprinted from Tawancy (2009), with permission from Elsevier.

Several other examples of stress corrosion causing the failure of heat exchangers can be found in the literature for both shell-and-tube heat exchangers (Otegui \& Fazzini, 2004; Guo et al., 2011; Qu et al., 2011; Ravindranath et al., 2012; El-Amoush et al., 2014; Corte et al., 2015; Xu et al., 2015; Corleto \& Argade, 2017) and plate heat exchangers (Turissini et al., 1997; Traubert \& Jur, 2012; Khodamorad et al., 2016). For two of these cases, it concerns corrosion fatigue (Otegui \& Fazzini, 2004; Ravindranath et al., 2012), while in the others, SCC was the main cause of failure.

\subsection{Erosion corrosion}

Erosion corrosion is the synergistic interaction between corrosion and erosion, caused by a relative motion between a corrosive fluid and a metal wall. The combined effect of the two phenomena is larger than corrosion or erosion separately. The phenomenon normally occurs under turbulent flow conditions. Surface material is removed by the fluid shear stress, and a protective corrosion film (e.g. formed on stainless steel or aluminium) can be destroyed by the motion of the fluid. The damage increases with increasing fluid velocity, and most metals have a critical velocity above which the corrosion rate strongly rises due to the destruction of the protective film (Wang et al., 2007). In seawater, where there is a high chloride concentration, stainless steel might not be able to establish passivity, causing the corrosion rate to increase with flow velocity (Revie \& Uhlig, 2008). A relationship between the flow velocity of seawater and the corrosion rate of carbon steel was proposed by LaQue (1948). This relationship was fitted to an exponential function by Guedes-Soares et al. (2011), as shown in Figure 10.

In plate heat exchangers, erosion corrosion can occur at the inlets and is more severe when the fluid contains abrasive solids such as sand particles (Wang et al., 2007). In shell-and-tube heat exchangers, the inlets are also

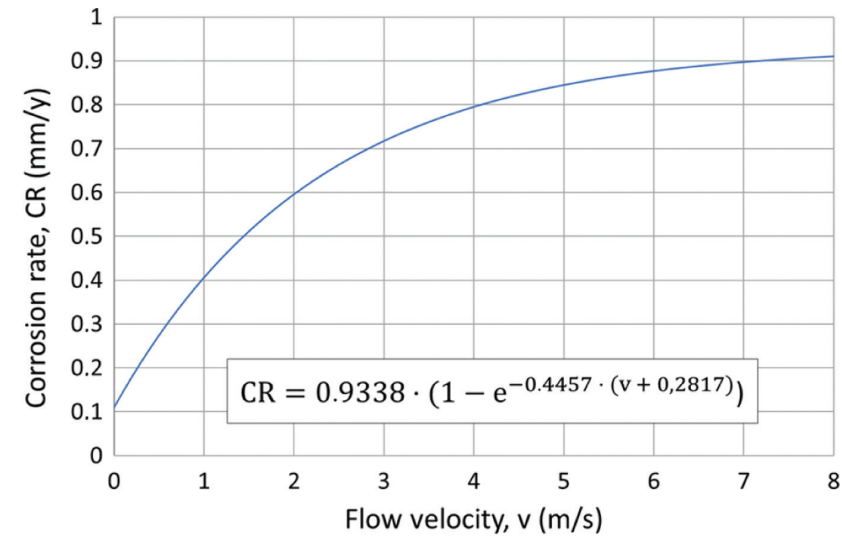

Figure 10: Effect of flow velocity on the corrosion rate of carbon steel in seawater.

prone to erosion corrosion, especially at the tube side, where this is often called inlet-tube corrosion (Walker, 1990).

Two other forms of wear, sometimes classified under erosion corrosion, are "cavitation erosion" and "fretting corrosion" (Walker, 1990). On the one hand, in the former, bubbles collapse on the surface. This often occurs in evaporators, but is also possible in non-boiling conditions at pressure drops, resulting from sudden changes in velocity. Fretting corrosion, on the other hand, is caused by a periodic rubbing motion between two metal parts. This often occurs in shell-and-tube heat exchangers at the tube-to-tube sheet joints or at the tube-baffle contacts. This increases the shell-side baffle bypass flow, leading to a less efficient heat exchanger.

Several examples of erosion corrosion can be found in the literature for shell-and-tube heat exchangers. Erosion corrosion was observed in several studies (Kuznicka, 2009; Eich, 2012; Yang et al., 2012; Li et al., 2013; Klein et al., 2014). Also, some examples of cavitation erosion (Reitz, 2002; Klenowicz et al., 2003) and fretting corrosion (Cassagne et al., 2010; Klein et al., 2014; Shahrani \& AlSubai, 2014) could be found. An example of a plate heat exchanger that failed because of fretting corrosion was described by Wassilkowska et al. (2016).

In the case described by Kuznicka (2009), pits were detected on the outside surface of the copper tubes in a shell-and-tube heat exchanger. Some of these pits were perforating the tube wall. Around the tubes, industrial water was flowing with an inlet temperature of $16^{\circ} \mathrm{C}$. The inside surface of the pits was smooth and free of corrosion products. The pits were positioned in the longitudinal direction of the tube and appeared as craters undercutting the metal. These observations led the author to believe that the pits were created by erosion corrosion. Also, the 
fact that the water contained some solids in suspension was thought to be the possible cause of the erosion corrosion. Most of the tubes on which the pits were discovered were laying in the same row: the row closest to the baffle edge. According to the author, the turbulence was most intense at this location, increasing the effect of erosion corrosion.

An example of a shell-and-tube heat exchanger that failed because of fretting corrosion is discussed by Klein et al. (2014). In a wastewater plant, hot vapours were used on the shell side. These vapours, however, contained some debris, fouling the outer surface of the tubes. This blocked the flow path in some areas of the heat exchanger, causing the fluid velocity to be higher in other regions. An oscillating behaviour of the tubes resulting from these high velocities caused the tubes to be in contact with each other, inducing fretting corrosion on each other. Figures 11 and 12, respectively, show friction marks on the outside of the tubes and worn-out holes in the baffle plates, created by the vibrating motion of the tubes.

Only one case of erosion corrosion (in the form of fretting corrosion) could be found for plate heat exchangers. The corrosion process was described by Cassagne et al. (2010), who investigated materials for plate heat exchangers. The fretting corrosion occurred at the contact points of adjacent plates.

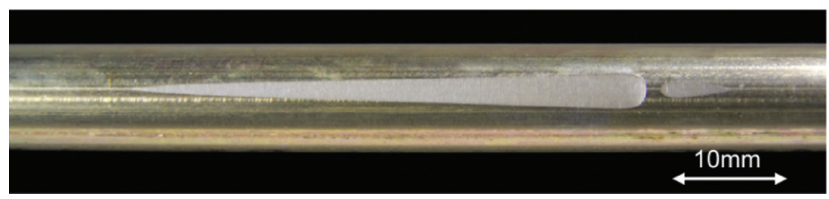

Figure 11: Friction marks on the outside of heat exchanger tubes. Reprinted from Klein et al. (2014), with permission from Elsevier.

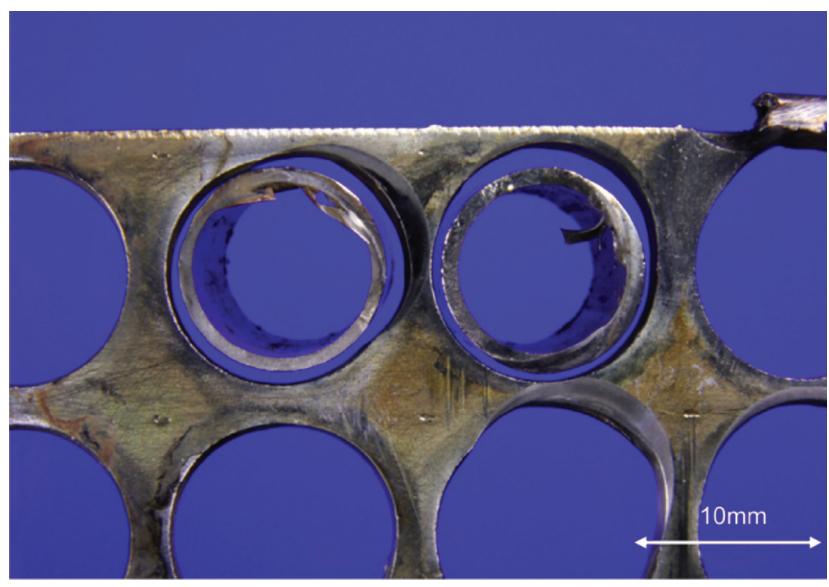

Figure 12: Worn-out holes in a baffle plate.

Reprinted from Klein et al. (2014), with permission from Elsevier.

\subsection{Intergranular corrosion}

In solid state, metals typically have a crystalline structure. Carbon steel has a body-centred cubic crystal structure; aluminium, copper, and austenitic stainless steel are face-centred cubic; and magnesium has hexagonal closepacked crystal lattice. During the solidification process, these crystals are formed as individual grains where the boundaries between the different grains are chemically more active (Walker, 1990).

Narrow regions along the grain boundaries can be corroded with only negligible attack on the grains themselves. This can cause the metal to disintegrate or lose its strength. Intergranular corrosion often occurs on welded structures of the widely used type 304 stainless steel. Operation at high temperatures, like an improper heat treatment or welding, can cause the depletion of the alloying element chromium near the grain boundaries in a process called sensitisation. These chromiumdepleted regions have lost their corrosion resistance, and what remains are the characteristics of the base metal (Kuppan, 2000). The chromium forms chromium carbides, because at these temperatures, the carbides are insoluble and for them to precipitate at the grain boundaries, they must obtain chromium from the surrounding metal. When the corroding metal is under a tensile stress, corrosion cracks can form along the grain boundaries. This phenomenon is termed intergranular SCC (Roberge, 2000).

From the examples given in the section on stress corrosion, the cracks discussed in several publications were intergranular (Turissini et al., 1997; Guo et al., 2011; Corleto \& Argade, 2017). Intergranular cracks (without the application of stresses) were found in the cases discussed by Ifezue and Tobins (2015) (together with pitting) and Chandra et al. (2010). Figure 13, from the work of Ifezue and Tobins (2015), clearly shows intergranular corrosion of a section of an aluminium tube, which typically results

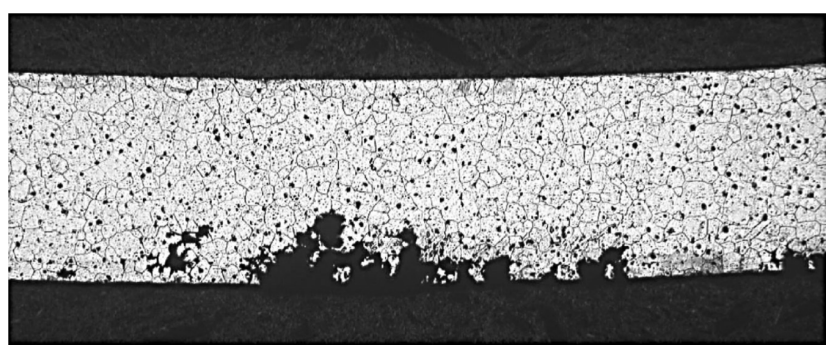

Figure 13: Intergranular corrosion of an aluminium tube. Reprinted by permission from Springer Nature: Journal of Failure Analysis and Prevention, Ifezue and Tobins (2015), Copyright 2015. 
from inappropriate heat treatment, e.g. during material production.

\subsection{Galvanic corrosion}

When two dissimilar metals are electrically connected and are in contact with an electrolyte, a galvanic cell is created and a potential difference exists over the two metals. In this bimetallic couple, the metal with the lowest potential, the anode, will start to corrode. The more noble metal will behave as a cathode, and its surface will remain unaffected (Roberge, 2000). In this context, it must be added that the potential of a metal depends on the characteristics of the electrolyte as well. Consequently, it is possible that for two dissimilar metals, one metal is anodic with respect to the other in one electrolyte, while it behaves cathodic with respect to the same other metal in a different electrolyte. Galvanic corrosion can also happen on a single metal, caused by local imperfections, local differences in the chemistry of the electrolyte (e.g. an oxygen concentration cell), or metallic deposits on the surface (Wang et al., 2007).

Galvanic corrosion is common in shell-and-tube heat exchangers at the contacts between the tubes and the baffles or tube sheets when different metals are used for those parts. Also, the contacts between the baffle and the shell are sensitive areas (Kuppan, 2000). In plate heat exchangers, galvanic corrosion can exist at welded, brazed, or soldered joints (Wang et al., 2007). One specific example of galvanic corrosion was already mentioned in Section 1. Parrott (2014) described the failure of a shell-and-tube heat exchanger made from carbon steel with a titanium cladding on an offshore gas production platform. In this case, the carbon steel was anodic to the titanium and corroded. Another example of galvanic corrosion where carbon steel was anodic to titanium was discussed by Yang et al. (2012) in a failure analysis of a shell-and-tube heat exchanger (caused by a combination of corrosion mechanisms) in a nuclear power plant. One last illustration of the need to avoid combining dissimilar metals is the failure analysis of Mousavian et al. (2011). In a shell-and-tube heat exchanger, used to cool oil with cooling water, the tubes, tube sheet, and gaskets were made of copper, carbon steel, and aluminium, respectively. After being used for only 4 months, the oil and water mixed because both the gaskets and the tube sheets corroded. Galvanic corrosion was determined to be the main cause of failure. The concept of galvanic corrosion is rather well known, so the mistake to bring different metals into contact with each other is only seldom made.

\subsection{Selective leaching}

Selective leaching or de-alloying is a form of galvanic corrosion on a microscopic scale where one alloying element is preferentially attacked over the other alloying elements in the matrix material. As a result, the remaining structure is weakened (Roberge, 2000). A common example is the removal of zinc from brass (de-zincification) in stagnant waters. Also, the removal of aluminium from aluminium brass in acidic solutions or nickel from cupronickel alloys under conditions of high heat flux (respectively called dealuminiumification and de-nickelification) is reported in industry (Kuppan, 2000). Addition of appropriate alloying elements is frequently quoted to be a viable strategy against selective leaching. For example, de-zincification of brass can be prevented in most aggressive environments by adding arsenic as alloying element to the brass (Ravindranath et al., 2012).

According to Wang et al. (2007), failures caused by selective leaching are not common in plate heat exchangers, as they can be avoided by selecting an appropriate material for each application. One example was found in the literature where cupronickel tubes in a shell-and-tube heat exchanger experienced de-nickelification (Cincera et al., 2012). The failure analyses in publications by Qu et al. (2011), Ravindranath et al. (2012), Li et al. (2013), and Ranjbar (2010) mention de-zincification as one of multiple causes of failure of a shell-and-tube heat exchanger.

In the example discussed by Ranjbar (2010), tubes made of yellow brass were used in a shell-and-tube heat exchanger. In the tubes, circulating cooling water flowed to condense the steam on the shell side. Several tubes experienced severe fouling and even plugging, causing the velocity to increase in the tubes that were not plugged. The flow in these tubes was rapid with a high turbulence intensity. Additionally, the metal was weakened, because zinc was leached from the copper alloy. This weakening, in combination with the turbulent motion, caused severe erosion. A section that de-zincified can be seen in Figure 14. The original brass had a yellow colour, while the de-zincified area has a red colour, as one typically observes for pure copper.

\subsection{Hydrogen damage}

Hydrogen can cause damage of a metal in different ways. Atomic hydrogen $\mathrm{H}$ (not the molecule $\mathrm{H}_{2}$ ) is the smallest atom and is often able to diffuse in the metal lattice interstitially at a measurable rate, along grain boundaries and along dislocations. Dislocations often play a crucial role 


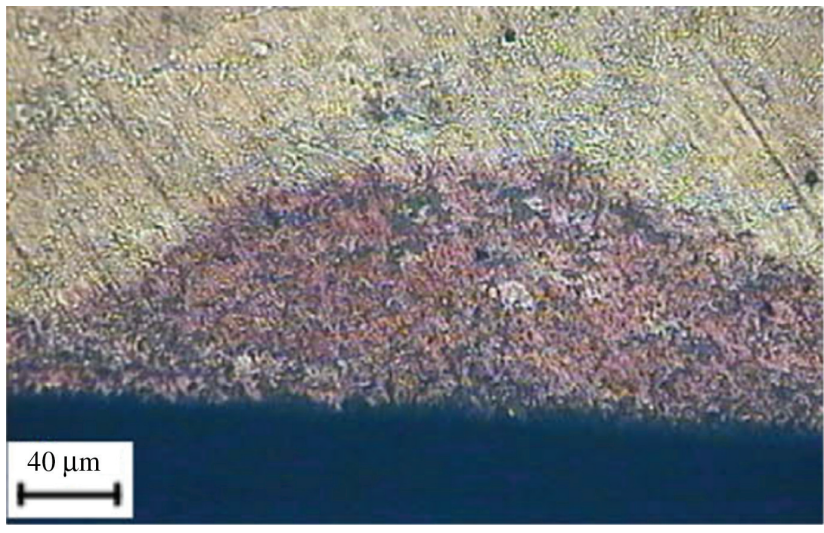

Figure 14: De-zincification of the inner surface of a yellow brass tube. Reprinted from Ranjbar (2010), with permission from Elsevier.

in hydrogen-related failure (Depover \& Verbeken, 2018). Atomic hydrogen can be produced by the cathodic reaction of the corrosion process, while the formation of $\mathrm{H}_{2}$ during the cathodic reaction can be caused by the presence of certain chemical species (so called "poisons", like $\mathrm{H}_{2} \mathrm{~S}$ ) (Roberge, 2000).

A first form of corrosion damage caused by atomic hydrogen is hydrogen blistering. This is caused by atomic hydrogen collecting at internal defects, close to the sample surface. In these cavities, it recombines to gaseous $\mathrm{H}_{2}$, building up very high internal pressures. This causes blisters to form on the metal surface. Another form of hydrogen damage is hydrogen-induced cracking (HIC), where the metal is embrittled by the present hydrogen. When stressed, the normally ductile metal will fail with a significantly reduced elongation. This form of corrosion is called sulphide stress cracking when the environment in which the HIC occurred contains $\mathrm{H}_{2} \mathrm{~S}$ (Roberge, 2000). At elevated temperatures $\left(>232^{\circ} \mathrm{C}\right)$ and high pressures $(>7$ bar), molecular hydrogen can dissociate to atomic hydrogen on steel surfaces and diffuse into the steel (Groysman, 2017). At grain boundaries, dislocations, and inclusions (such as carbides) in the steel, it can form methane $\left(\mathrm{CH}_{4}\right)$. This process, called HTHA, decarburises the steel, reducing its mechanical properties.

Titanium is susceptible to hydrogen damage due to hydride formation, as illustrated by the paper by Yang et al. (2012). In this study, the leakage of titanium tubes of a heat exchanger in a nuclear power plant is investigated. Some galvanic corrosion and crevice corrosion produced hydrogen, leading to HIC.

HTHA was indicated to be the cause of the catastrophic failure and explosion of a heat exchanger in the refinery plant mentioned in Section 1 (CSB, 2010; Marsh, 2016). The shell-and-tube heat exchanger was made from carbon steel with a stainless-steel cladding and used to heat naptha for the removal of sulphur, nitrogen, and oxygen impurities. The formation of cracks by HTHA occurred near the welds and was facilitated because the shell did not receive an appropriate post-weld heat treatment.

\subsection{Microbiologically induced corrosion}

Microbiologically induced corrosion (MIC) is described in a paper by Dexter (2003). Microorganisms, including bacteria, algae, and fungi, are encountered not only in almost every natural aqueous environment but also in several industrial fluids. They are, for example, very common in cooling water systems, where they reduce the heat transfer rates and increase the pressure drop over the condenser (Rao \& Nair, 1998). When these organisms attach to a surface, a biofilm is formed that will influence corrosion. The microorganisms can initiate corrosion, which would not occur in the same environment without microorganisms. The biofilm can also change the type of corrosion (e.g. from uniform to localised corrosion) or increase or decrease the corrosion rate. It is, however, also possible that the biofilm does not influence corrosion. The possible influences of microorganisms on corrosion are summarised by Dexter (2003) and schematically represented in Figure 15.

A failure analysis was done by Huttunen-Saarivirta et al. (2012) on a stainless-steel (type 304) shell-and-tube heat exchanger that was used for only 36 months. On the surface of the shell, where the cooling water flows, corrosion tubercles (Figure 16) were found. Some of them penetrated the metal (with an original thickness of $6.2 \mathrm{~mm}$ ), while most of them had a depth of $2-4 \mathrm{~mm}$. The investigation showed that the metal had both a major austenite phase and a minor ferrite phase. There was a micro-scale

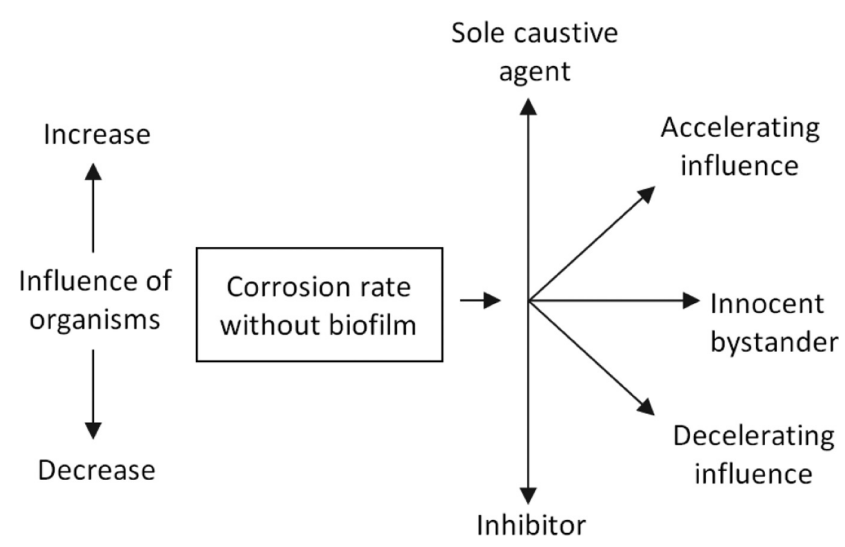

Figure 15: Influence of a biofilm on the corrosion rate. 


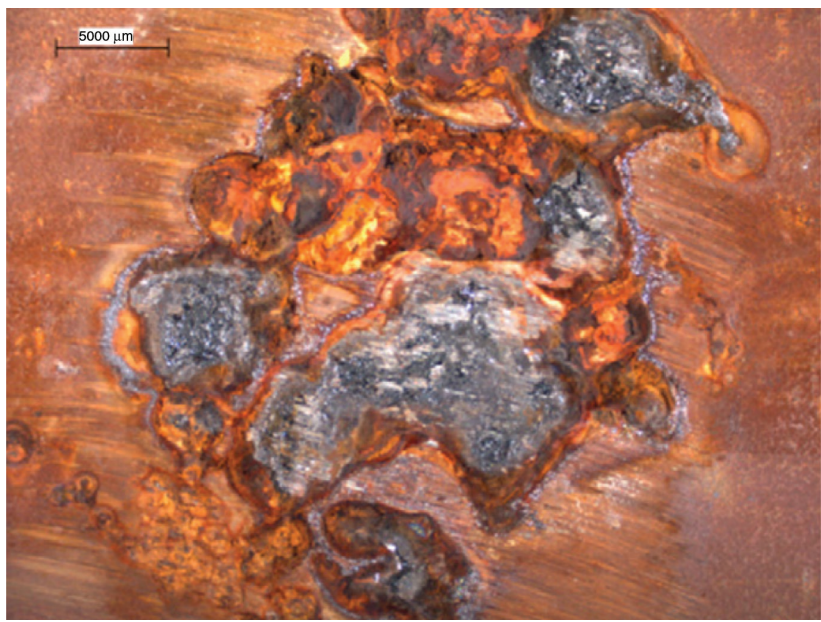

Figure 16: Tubercles observed on the shell surface of a heat exchanger.

Reprinted from Huttunen-Saarivirta et al. (2012), with permission from Elsevier.

surface roughness at this ferrite phase, giving bacteria the possibility of attachment, subsequently leading to oxygen concentration cells. These cells locally induced corrosion and created the tubercles.

In the literature, more examples can be found of heat exchangers that failed due to MIC (Rao \& Nair, 1998; Abraham et al., 2009; Sharma, 2014; Rizk et al., 2017).

\section{Corrosion and heat transfer}

In this section, the interaction between corrosion and heat transfer is discussed. The first part explains how a metal surface can experience differences in the corrosion process under heat transfer conditions, compared to when the temperature distribution is uniform. In the second part, it is demonstrated how corrosion can affect heat transfer and the performance of a heat exchanger.

\subsection{Influence of heat transfer on corrosion}

When heat is transferred from a solid wall to a fluid (or vice versa), a temperature gradient exists, causing the fluid near the surface to have a different temperature than the bulk fluid (Welty et al., 2009). The temperature of the boundary layers near the wall depends on the temperatures of the bulk fluid, the conductive thermal resistance of the heat transfer surface, and the relative value of the convection coefficients. This can be illustrated with a thermal resistance network, as illustrated in Figure 17.

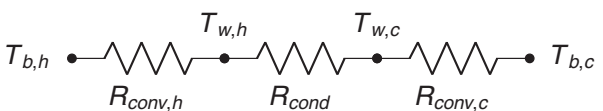

Figure 17: Thermal resistance network for heat transfer from a hot to a cold fluid over a heat transfer surface.

This figure shows the bulk $\left(T_{b}\right)$ and wall $\left(T_{w}\right)$ temperature on the hot $(h)$ and the cold $(c)$ sides, the two convective resistances $\left(R_{\text {conv }}\right)$, and the conductive resistance $\left(R_{\text {cond }}\right)$.

The kinetics of electrochemical reactions (such as corrosion of a metal surface) normally increase with increasing temperature. An exponential relationship, which is reflected in the Arrhenius equation, usually exists between temperature and reaction rates (Silverman, 2003). This implies that when a corrosive fluid is heated, the temperature in the boundary layer near the wall is higher and corrosion kinetics will be faster than kinetics driven by the bulk temperature $\left(T_{w, c}>T_{b, c}\right)$. However, when a corrosive fluid is cooled, the metal temperature will be lower than the bulk fluid temperature $\left(T_{w, h}<T_{b, h}\right)$ and the corrosion kinetics are reduced (Moore \& Smith, 1967). A schematic illustration of the temperature profile over the fluids, the boundary layers, and the surface is given in Figure 18.

The local differences in temperature also cause different solubility products of substances in the fluid. For most species, the solubility increases with increasing temperature, while some have inverted characteristics (Stumm \& Morgan, 2012). Corrosion products are typically among the first category. As explained, the temperature of the bulk fluid in a heat exchanger is different than the metal temperature or the temperature of the fluid in a boundary layer near the wall. Heat transfer to the liquid can cause the corrosion products to dissolve instead of forming a protective layer, because their solubility near the wall is high. This can increase the corrosion rate. When a liquid
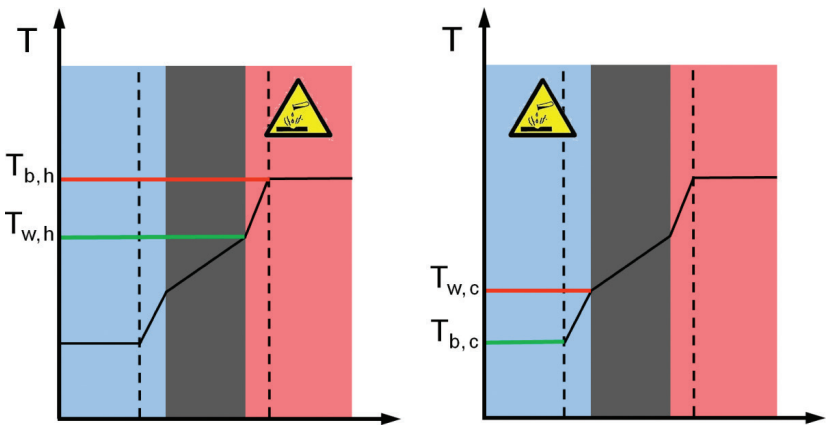

Figure 18: Temperature profile when a corrosive fluid is being cooled (left) and heated (right). 
is cooled, the corrosion products do not have the tendency to dissolve, but form an adherent scale, protecting the surface from further corrosion (Ross, 1967). In addition to the corrosion products, the corrosive species causing the degradation of the metal also experience this change in solubility. Dissolved oxygen, for example, has an inverted solubility characteristic, so it is less soluble at higher temperatures. The mass transport of oxygen from the bulk fluid to the hotter metal is difficult, so this might counteract the higher corrosion rates expected for a heated fluid (Ross, 1967).

Not only a temperature gradient between the fluid in the boundary layer and the bulk fluid can affect corrosion. On the heat transfer surface itself, different areas can have another temperature. According to Roberge (2000), hot metal is anodic to the same metal at a lower temperature. This is a cause of thermogalvanic corrosion, which was mentioned by Ross (1967), Green (1967), and Maylor (1967). Ross (1967) and Green (1967) indicated this phenomenon with the term "hot-spot corrosion". In heat exchangers, local overheating typically occurs under deposits or because of damaging behaviour of the flow, like e.g. the impingement of steam, an acceleration at blockages, or the stagnation in enlargements. This hot-spot corrosion is discussed in more detail by Francis (1987). According to this author, it is common in copper alloy heat exchanger tubes, and its process depends on the temperatures and the chemicals in the water. Several examples can be found of hot-spot corrosion in copper tubes in desalination plants (Todd, 1967; Powell \& Michels, 2000; Abouswa et al., 2007).

Additional complications occur during a change of phase of the fluid. When a liquid starts boiling, small bubbles of vapour are produced on the surface (nucleate boiling). These bubbles can collapse and cause cavitation erosion of the surface, possibly removing a protective layer (Green, 1967; Ross, 1967).

During the condensing of a vapour, a layer of liquid forms on the metal. Gases in the vapour may dissolve in the condensate, causing localised corrosion on the metal surface (Moore \& Smith, 1967; Ross, 1967). This process is sometimes called condensate corrosion (Boffardi, 2003) and is the cause of the failure of the heat exchanger discussed by Julian et al. (2015), described in the part about pitting corrosion.

A last type of corrosion induced by heat transfer is “liquid-line corrosion”, described by Green (1967). When a diluted acid, flowing through a tube, is heated, the water can evaporate. A more concentrated solution is remaining, which might be corrosive to the metal, although the original diluted acid was not a problem. Localised corrosion then occurs at the point where the solution reaches a critical concentration.

\subsection{Influence of corrosion on heat transfer}

Not only does heat transfer have an influence on the corrosion process, but corrosion can also negatively affect the thermohydraulic performance of the heat exchanger (Edwards, 2008; Mousavian et al., 2011).

This is illustrated by the study of Zhao et al. (2012), where the effect of corrosion on the performance of finand-tube heat exchangers was investigated. The heat exchangers were subject to accelerated corrosion by keeping them in a standardised salt spray chamber for 48 or $96 \mathrm{~h}$. The performance after being corroded was evaluated based on the cooling capacity, the heat transfer coefficient, the thermal resistance, and the air-side pressure drop, and compared to the performance before the test. All heat exchangers had copper tubes, while the fins were either copper or aluminium. The influence on the cooling capacity can be seen in Figure 19. The cooling capacity of the heat exchangers with the copper fins is highest for all flow rates, both before and after corrosion, due to the higher conductivity of copper than aluminium. The reduction in performance after the corrosion is larger for the samples with the aluminium fins (maximally 19\%) than for the samples with the copper fins (maximally 2\%).

In the study by Zhao et al. (2012), the decrease in heat transfer is attributed to a layer of corrosion products that formed on the fins (mainly $\mathrm{Al}_{2} \mathrm{O}_{3}$, aggravated by

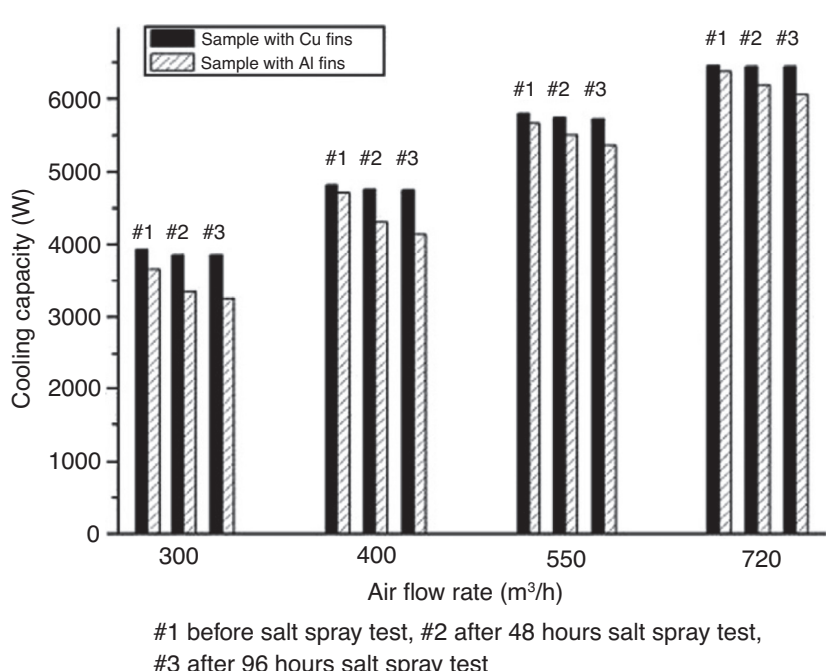

Figure 19: Influence of corrosion on the cooling capacity of a finand-tube heat exchanger.

Reprinted from Zhao et al. (2012), with permission from Elsevier. 
Table 1: Thermal conductivity of various metals and metal oxides.

\begin{tabular}{|c|c|c|c|}
\hline Metal & $\begin{array}{l}\text { Thermal conductivity } \\
\left(\mathrm{W} \mathrm{m}^{-1} \mathrm{~K}^{-1}\right)\end{array}$ & Oxide & $\begin{array}{l}\text { Thermal conductivity } \\
\left(\mathrm{W} \mathrm{m}^{-1} \mathrm{~K}^{-1}\right)\end{array}$ \\
\hline Aluminium & 237 (Kakaç et al., 2012) & Aluminium oxide $\left(\mathrm{Al}_{2} \mathrm{O}_{3}\right)$ & 25 (Weast, 1981)-40 (Kakaç et al., 2012) \\
\hline Copper & 401 (Kakaç et al., 2012) & Copper(II) oxide (CuO) & 20 (Kakaç et al., 2012) \\
\hline Carbon steel & 52 (Weast, 1981) & Iron oxide & 0.58 (The Engineering ToolBox, 2017) \\
\hline Stainless steel & 17 (Weast, 1981) & Chromium(III) oxide $\left(\mathrm{Cr}_{2} \mathrm{O}_{3}\right)$ & 10-33 (Shackelford \& Alexander, 2001) \\
\hline Titanium & 20 (Weast, 1981) & Titanium dioxide $\left(\mathrm{TiO}_{2}\right)$ & $11.7(\mathrm{AZoM})$ \\
\hline
\end{tabular}

the galvanic cell that exists between the aluminium fins and the copper tubes). This additional thermal resistance caused by corrosion products also occurs in other heat exchangers constructed from different materials (Turissini et al., 1997; Ranjbar, 2010; Yang et al., 2012). Table 1 lists the thermal conductivity of some metals commonly used in the construction of heat exchangers and some of the oxides that typically result from corrosion of these metals. It can be seen that the thermal conductivity of the corrosion products is often significantly lower than that of the base metal. This could be expected as oxides are ceramics, which usually are thermal insulators because of their lack of large numbers of free electrons (Callister \& Rethwisch, 2011).

\section{Prevention of corrosion}

\subsection{General considerations and guidelines}

Many problems with heat exchangers for corrosive applications can be avoided by using good practice in the material selection, during the design phase, and during the operation of the device.

Material selection is one of the most important aspects in avoiding corrosion of a heat exchanger in a specific fluid. Some metals are better suited for a certain environment than others, and the most appropriate material should be chosen (Tuthill, 1990). If only expensive, highly alloyed materials can resist the environment, a plate heat exchanger is preferred, because these require less material than a shell-and-tube heat exchanger. If, however, a shell-and-tube heat exchanger would be preferred, the corrosive fluid has to flow in the tubes, as then the shell can be made of a cheaper metal (Kakaç et al., 2012). For shell-and-tube heat exchangers with different corrosive fluids on the shell side and the tube side, bimetallic tubes are sometimes used. These tubes are made from two different metals, which are usually co-extruded and have successfully been used to reduce weight and improve corrosion resistance in heat exchangers (Knezevic et al., 2014). When using different metals, one should, however, be careful to avoid galvanic corrosion (see Section 2.7), not only with bimetallic tubes but also for tube and tube sheet combinations or with smaller elements like bolts (Kuppan, 2000). When the use of two different metals cannot be avoided, they should be electrically insulated. The anodic (corroding) part should be readily replaceable and have a larger surface than the cathode (area effect) (Walker, 1990). To protect the metal from the aggressive environment, coatings can be applied on the surface. Coatings generally do not provide any mechanical strength, but only isolate the material from the fluid to preserve its strength and integrity (Roberge, 2000). They are typically classified into three groups: metallic, organic, and inorganic (non-metallic) coatings.

- Metallic coatings can be applied to a substrate in several ways, for example hot dipping, electroplating, spraying, cementation, and diffusion (Revie \& Uhlig, 2008). The choice of the type of coating process depends on several factors such as the required corrosion resistance or the anticipated lifetime of the coating. Nickel, zinc (e.g. galvanising of steel), lead, tin, aluminium, cadmium, and chromium are some examples of metals that are often applied as coating on a substrate made of another material (Carter, 1977). The coating can be both cathodic or anodic with respect to the substrate.

- Paints, resins, lacquers, varnishes, and plastic linings are all categorised as organic coatings (Roberge, 2008). They are typically designed to have a high impermeability and an inhibitive function to the corrosion process while they can also contain cathodically protective pigments.

- Inorganic (non-metallic) coatings can be divided into two categories (Roberge, 2008). Hydraulic cements, ceramics, carbon, silicates, and glass are applied on the surface of the protected substrate. Other treatments change the natural characteristics of the oxide 
film, with a low corrosion resistance, into a different protective film or metallic oxide with a higher corrosion resistance in the specific operational environment. Some examples here include anodising, nitriding, and phosphatising.

Each of these types of coatings has been applied in heat exchangers to protect the heat transfer surface from a corrosive environment (Chang \& You, 1997; Fedrizzi et al., 2008; Jong-Soon et al., 2009). In addition to the protection from corrosion, coatings can also fulfil a different role. Wang and Chang (1998) tested hydrophilic coatings to improve the condensate draining in fin-and-tube heat exchangers. This better draining could reduce the pressure drop up to $40 \%$. Also in dehumidifying heat exchangers, hydrophilic coatings have successfully been applied (Hong \& Webb, 2000). Hydrophobic coatings, however, have also been tested in heat exchangers. Das et al. (2000) applied such coatings on copper tubes to promote dropwise condensation in a condenser. The achieved heat transfer coefficients were, in some cases, 14 times higher than with filmwise condensation. A disadvantage of coatings is that they usually have a significantly lower thermal conductivity - lower than that of the base metal. In gas turbines, for example, inorganic coatings are applied because of their lower thermal conductivity to reduce the temperature of the airfoils (Strangman, 1985). In heat exchangers, their thickness is normally only in the order of micrometres (Roberge, 2000), so their effect on the heat transfer is limited.

Apart from the material selection, some other measures can be taken during the design phase to reduce the risk of corrosion-based failures. When the conditions to which the heat exchanger will be exposed can cause uniform corrosion, the construction material is typically made thicker than required to guarantee the necessary strength over the entire lifetime. This extra material is called the corrosion allowance. This strategy is, however, not possible with plate heat exchangers, because the plates need to be very thin, both to maintain a compact form and for production purposes (Kakaç et al., 2012). Also during the design phase, sharp edges should be avoided, because these can induce corrosion fatigue or crevice corrosion. In general, crevices should always be avoided. When they cannot be avoided, they should either be filled or be wide and shallow. The connection between the tubes and the tube sheets in shell-and-tube heat exchangers is a sensitive location for crevice corrosion. One possibility to avoid these crevices is to weld the connection instead of rolling. When using a rolled connection, the difference between the outer diameter of the tubes and the inner diameter of the holes in the tube sheets before rolling should be as small as possible. Otherwise, residual stresses after rolling could induce SCC (Kuppan, 2000). To completely rule out leakages from one fluid to the other, special designs with double tube sheets in shell-and-tube heat exchangers or double-wall plates in plate heat exchangers can be used (Kuppan, 2000). With these designs, any leakage at the tube-tube sheet interface or through a pit in a plate will be to the environment instead of to the other fluid.

Special care should also be taken when designing the flow path. Dead spaces or areas with low velocities have to be avoided, because they can induce pitting or crevice corrosion. Dead spaces can, for example, exist in vertical shell-and-tube heat exchangers above the upper tube sheet as a result of a wrong rolling procedure where the tubes protrude the tube sheet and a crown is produced in the tube sheet (Collins, 1955). An incorrectly and a correctly rolled tube bundle are shown in Figure 20. The fluid velocity should also not be too high, as this can cause erosion corrosion. Erosion corrosion at the first centimetres of the tubes is common and often called tube-inlet corrosion. It can be prevented by inserting a short, wearresistant tube in the wearing inlets, similar to the principle of bimetallic tubing (Kuppan, 2000). The outer surface of the tubes located near the inlet of the shell is also sensitive to erosion corrosion. Protection can be provided under the form of wear-resistant impingement plates or angle tube protectors, shown in Figures 21 and 22, respectively (Kuppan, 2000). Another type of corrosion that can be avoided by carefully designing the flow path is fretting corrosion caused by flow-induced vibrations of the tubes. Kuppan (2000) proposed changing the fluid velocity or stiffening the tubes with tube support plates, while Walker (1990) also mentioned the use of coatings to roughen the surface and dampen vibrations.

Pakhomov and Parshin (1993) gave some recommendations for the thermal design. They defined the term

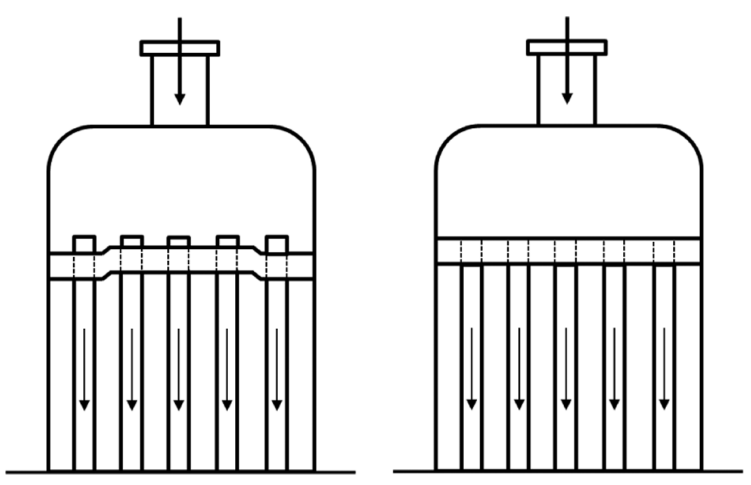

Figure 20: Dead space in a vertical heat exchanger (left) and a correctly rolled heat exchanger (right). 


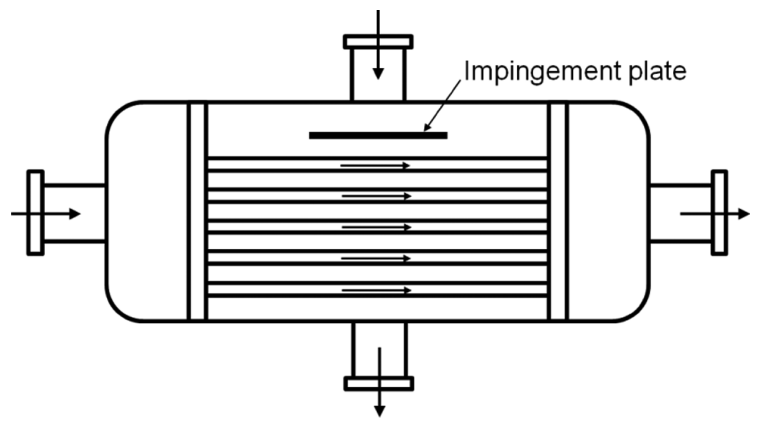

Figure 21: Impingement plate in a shell-and-tube heat exchanger.

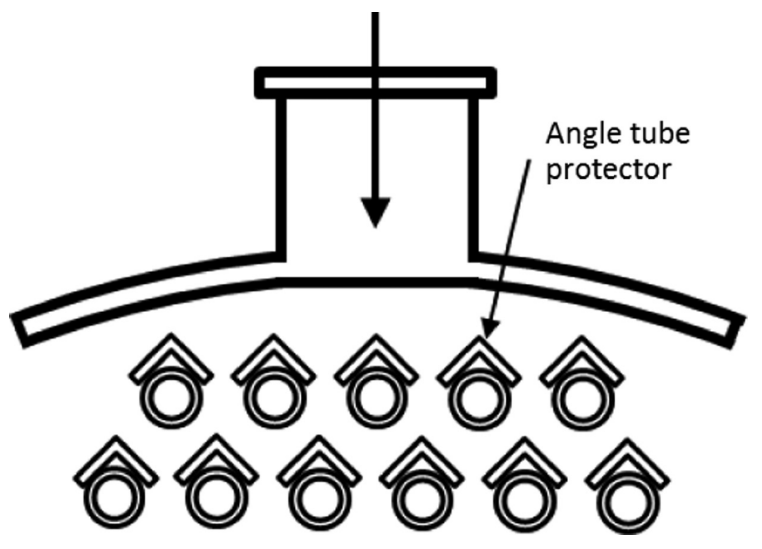

Figure 22: Angle tube protectors in a shell-and-tube heat exchanger.

Republished with permission of Taylor \& Francis Group LLC, from Kuppan (2000); permission conveyed through Copyright Clearance Center, Inc.

"effective temperature" as the temperature of the fluid in the boundary layer near the wall, which is, in most cases, closer to the wall temperature than to the bulk fluid temperature. Pakhomov and Parshin advised to maximise the heat transfer coefficient on the side of the heat exchanger where the coolest fluid is present. This will result in the lowest possible effective temperature and reduced corrosion kinetics. In the thermal resistance network of Figure 17, this would mean minimising $R_{c o n v, c}$ to reduce $T_{w, c^{*}}$ Figure 23 shows the temperature profile for heat transfer over a heat transfer surface for the case where a corrosive fluid is being cooled (left) or heated (right). For both cases, the temperature profile is illustrated with the highest heat transfer on both the hot and cold sides. It can be seen that in both cases, the lowest effective temperature occurs when the highest heat transfer is on the side of the cold fluid.

In addition to a careful design, attention should be paid to the operation of the heat exchanger. Possible problems potentially inducing corrosion are off-design
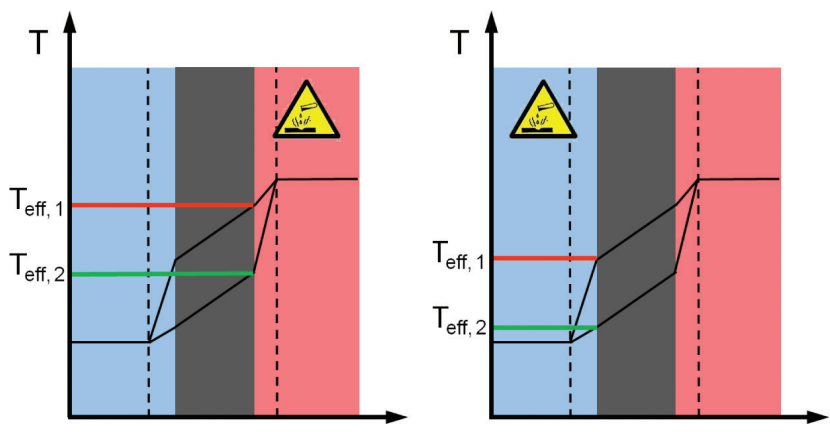

Figure 23: Effect of heat transfer coefficient on the effective temperature near a heat transfer surface.

temperatures or concentrations, non-complete removal of oxygen, and non-uniform distribution of corrosion inhibitors (Kuppan, 2000). A good practice is to filter out abrasive particles, stringy debris, and organisms to avoid erosion corrosion and MIC. Cleaning of the heat transfer surface should be done regularly, because deposits on the metal can induce pitting, crevice corrosion, MIC, and de-alloying. When MIC is a potential problem, organisms attached to the surface can be killed by temporarily recirculating the cooling water, increasing its temperature to a level where the organisms cannot survive. Finally, when performing maintenance, care should be taken to avoid residual stagnant pools of fluid in the device. Of course, this is only possible when the design allows complete drainage. As mentioned before, low velocities can induce pitting corrosion. Furthermore, some of the remaining liquid can dry up, leaving a more concentrated and corrosive solution. Figure 24 illustrates a bad and a good design (Elliot, 1987).

Of the many considerations described above, several recur as recommendations in failure analyses. In the references made in the discussion on the different types of corrosion, the recommendations encountered most often are a change of the environment (e.g. by the addition of
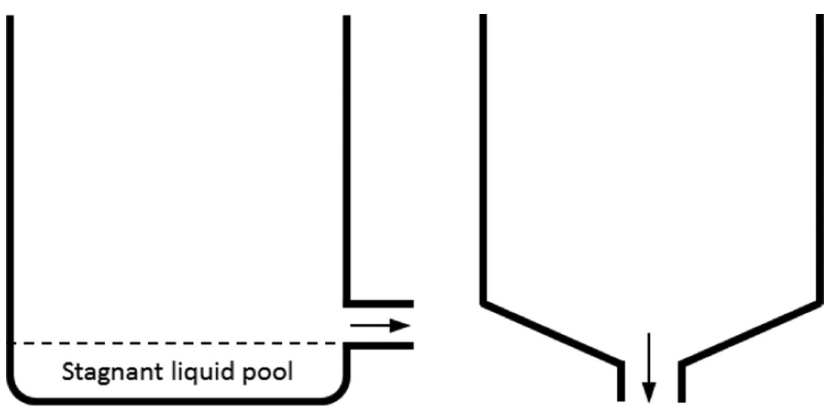

Figure 24: Design of a vessel allowing incomplete (left) and complete (right) drainage. 
corrosion inhibitors) and the choice of a different construction material. The advice to change the flow configuration is also often given. It might, in some cases, be necessary to either increase or decrease the flow velocity or to reduce the level of turbulence in the flow. Preventive measures like periodic cleaning or regular non-destructive testing of the heat exchanger are also repeatedly recommended. Finally, it is sometimes proposed to change the mechanical design or production process. An overview of which preventive strategy is given in the failure analyses can be found in Table 2.

\subsection{Cathodic protection}

As explained earlier, corrosion processes consist of a cathodic and an anodic reaction. The anode is the reactive metal and will corrode. Only features such as hydrogen-induced damage happen at the cathode. Corrosion of a structure can be avoided by altering the circumstances such that the protected surface becomes a cathode. This cathodic protection can be done by reducing the corrosion potential and is in practice achieved by two possible strategies (Roberge, 2008). A "sacrificial anode" can be connected to the structure to be protected. This part is made from a metal that is less noble in the galvanic series than the protected structure and will, by consequence, suffer corrosion instead of the protected metal. Zinc and magnesium are often used in combination with steel. When this sacrificial anode has been extensively consumed, it is simply replaced by a new one. This method is easy and relatively cheap; however, the provided protection is uncontrollable and frequent replacement of the anodes might be necessary. The second option is to use "impressed current cathodic protection" (ICCP). The protected structure is connected to an anode through

Table 2: Recommendations given in failure analyses to prevent corrosion.

\begin{tabular}{|c|c|c|c|c|c|c|}
\hline & $\begin{array}{l}\text { Change } \\
\text { environment }\end{array}$ & $\begin{array}{l}\text { Different } \\
\text { material }\end{array}$ & $\begin{array}{l}\text { Change flow } \\
\text { configuration }\end{array}$ & $\begin{array}{l}\text { Periodic } \\
\text { cleaning }\end{array}$ & $\begin{array}{l}\text { Regular } \\
\text { testing }\end{array}$ & $\begin{array}{l}\text { Change mechanical } \\
\text { design }\end{array}$ \\
\hline Abouswa et al. (2007) & & & & & $x$ & \\
\hline Abraham et al. (2009) & $x$ & & & $x$ & & \\
\hline Allahkaram et al. (2011) & & $x$ & & $x$ & & \\
\hline Chandra et al. (2010) & $x$ & $\mathrm{x}$ & $x$ & $x$ & & \\
\hline Cincera et al. (2012) & $x$ & & & $x$ & & \\
\hline Corleto and Argade (2017) & $x$ & & & & & \\
\hline Corte et al. (2015) & $x$ & $x$ & & & $x$ & \\
\hline Deen et al. (2010) & $x$ & & & & & \\
\hline Eich (2012) & $x$ & $x$ & & & $x$ & $x$ \\
\hline Ghayad et al. (2015) & $x$ & & & & & \\
\hline Guo et al. (2011) & & & & & & $x$ \\
\hline Ifezue and Tobins (2015) & $x$ & $x$ & & $x$ & & \\
\hline Julian et al. (2015) & & & $x$ & & & \\
\hline Kaul et al. (1995) & & & & & & $x$ \\
\hline Khodamorad et al. (2016) & & & $x$ & & & \\
\hline Klein et al. (2014) & $x$ & & & $x$ & $x$ & \\
\hline Klenowicz et al. (2003) & $x$ & & & & & \\
\hline Kuznicka (2009) & & & $\mathrm{x}$ & & & \\
\hline Mousavian et al. (2011) & $x$ & $x$ & & & & \\
\hline Ranjbar (2010) & & $x$ & $x$ & & & \\
\hline Ravindranath et al. (2012) & $x$ & $x$ & & & & \\
\hline Reitz (2002) & & $x$ & $x$ & & & \\
\hline Sanders and Iwand (2013) & & $x$ & & $x$ & & \\
\hline Shahrani and Al-Subai (2014) & & & & & $x$ & $x$ \\
\hline Sharma (2014) & $x$ & & & & & \\
\hline Tawancy (2009) & $x$ & & & & & \\
\hline Traubert and Jur (2012) & & $x$ & $x$ & $\mathrm{x}$ & & $x$ \\
\hline Turissini et al. (1997) & & $x$ & & & & \\
\hline Xie et al. (2015) & & $x$ & $x$ & & & \\
\hline Yang et al. (2012) & & & & & & $x$ \\
\hline Zheng et al. (2014) & $x$ & $\mathrm{x}$ & & $x$ & & \\
\hline
\end{tabular}


an external power source. Because of the electric current, impressed by this power source, the protected structure is cathodically polarised. Because of the anodic polarisation, anode materials with a passive surface in the electrolyte are preferred to limit the metal dissolution and the anode consumption rate.

Al-Hashem et al. (1997) investigated the possibility of cathodically protecting heat exchanger tubes in seawater at $45^{\circ} \mathrm{C}$. The tubes had an internal diameter of $1.27 \mathrm{~cm}$ and a length of $6 \mathrm{~m}$, and were made of a copper nickel alloy (UNS C71500). The cathodic protection was done with sacrificial anodes made from carbon steel and attached to both ends of the tubes. The potential of the tubes was recorded at six different places, and the current between the anodes and the tubes was measured with a zero resistance ammeter. The results indicated that the tubes could be protected over the entire length. In another study by Wigen et al. (2007), the possibility to use cathodic protection to prevent corrosion in small-bore stainless-steel tubes was investigated. In this research, a resistor-controlled sacrificial anode was used to protect the tubes. Although recommended practices advise a maximum length/diameter (L/D) ratio of 5 for carbon steel tubes, their calculations showed that this ratio depends on the electrical conductivity of the fluid, the diameter of the tube, the potential necessary for protection, and the required current density. It was found that for stainless-steel tubes, cathodic protection is possible for tubes with $\mathrm{L} / \mathrm{D}$ ratios up to 225 . The authors discussed a case where a heat exchanger with 10-m-long tubes was used for cooling with seawater in a plant. The original heat exchanger with tubes made from a copper-nickel alloy failed after only a couple of months. The new heat exchanger had super duplex tubes that were cathodically protected. After several years, no signs of corrosion were detected.

Care should, however, be taken when designing the cathodic protection system. In the condenser described in the failure analysis by Shalaby (2006), titanium tubes were coupled with Muntz tube sheets and carbon steel waterboxes. Aluminium sacrificial anodes were attached to the waterboxes to cathodically protect these waterboxes and the tube sheets from galvanic corrosion. Despite the sacrificial anodes (that were found consumed), the carbon steel, Muntz tube sheets, and titanium all suffered corrosion. Their research indicated that the main corrosion process was hydrogen embrittlement caused by the overprotection provided by the sacrificial anodes. The authors advised the plant operators to remove the aluminium anodes and to apply a coating to the waterboxes and the tube sheets. Similar findings were published by Fulford et al. (1987) and Tsai et al. (1987).
Several patents exist disclosing the use of cathodic protection in heat exchangers. Patents by Deivasigamani and Preiser (2013), Noboru et al. (1989), Inagaki et al. (2002), and Ivusic (2004) discuss the protection of shelland-tube heat exchangers. In the patent by Deivasigamani and Preiser (2013), both a zinc sacrificial anode and an impressed current system with an iron anode are installed in the end chambers. In Figure 25, the two anodes are indicated with 82 and 90 , respectively.

A different location, instead of the end chambers, where the anode (either as sacrificial anode or for ICCP) can be placed is in the piping just before the shell-andtube heat exchanger. This was done in the patent by Noboru et al. (1989) and can be seen in Figure 26.

In the patent by Inagaki et al. (2002), an invention is described where the goals were to both cathodically protect the tubes and to prevent biofouling of the tube sheet. In Figure 27, the brass tubes are indicated with $1 b$ and the tube sheet with $1 a$. On the tube sheet, a titanium sheet 4 is deposited. With controller 7 , the potentials of the cathode (the tubes) and the anode (the titanium sheet) are controlled so that oxygen evolves at the anode. This oxygen evolution prevents organisms in the seawater from fouling the surface. An additional controller 40 is used to

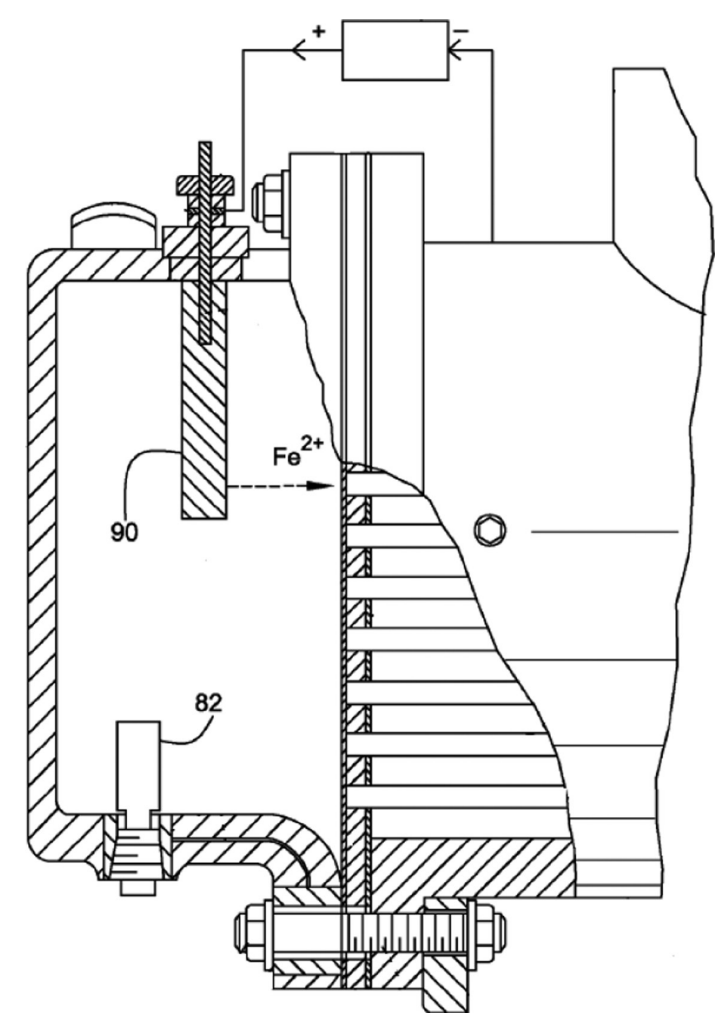

Figure 25: Cathodic protection of heat exchanger tubes by placing the anodes 82 and 90 in the end chamber (Deivasigamani \& Preiser, 2013). 


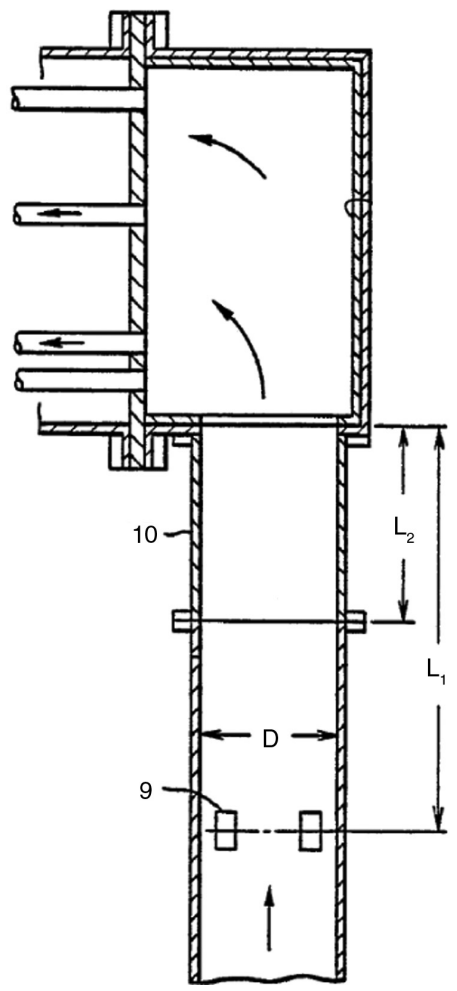

Figure 26: Cathodic protection of heat exchanger tubes by placing the anodes 9 in the piping 10 before the heat exchanger (Noboru et al., 1989).

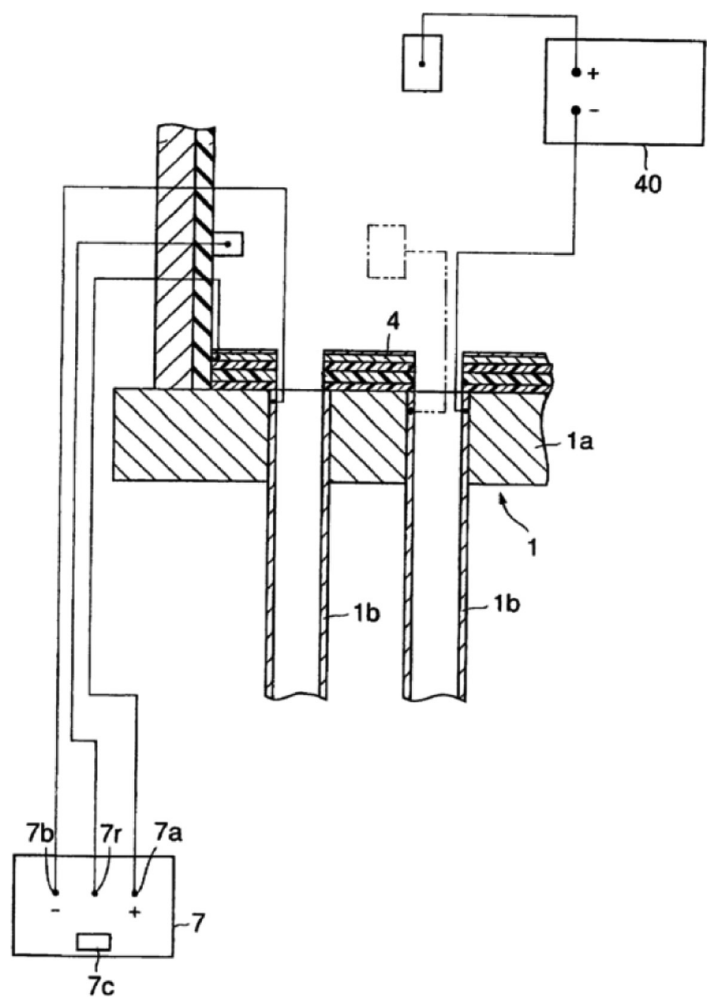

Figure 27: Cathodic protection system to prevent biofouling of the tube sheet and corrosion of the tubes (Inagaki et al., 2002). control the potential of the tubes so that they are cathodically protected.

The invention in the patent by Ivusic (2004) makes use of mobile anodes to protect the heat exchanger tubes. Several spheres with a diameter slightly smaller than the tube diameter are injected in the flow before the heat exchanger and are extracted from the flow after the device. These spheres are either made of metal or of polymer but with metallic elements on the surface. This metal needs to be less noble than the protected tubes, so they will behave as an anode when they come in contact with the tubes. The principle is illustrated in Figure 28.

Cathodic protection is not limited to shell-and-tube heat exchangers. The patents by Suzuki et al. (2015) and Terai et al. (1980) discuss the production of aluminium tube-fin heat exchangers where the fins have a different composition than the tubes. The fins act as sacrificial anodes to the tubes, preventing leakages caused by corrosion of the tubes.

Finally, the use of cathodic protection for plate heat exchangers is discussed in the patent by Graff et al. (2017). This patent discloses the placement of either sacrificial anodes or anodes for ICCP in the inlet channel.

\subsection{Anodic protection}

Another electrochemical method of reducing corrosion is anodic protection. As with ICCP, an external power source is required. It serves, however, to shift the potential of the protected metal in the anodic direction. For some metals, like e.g. stainless steels or titanium, this does not increase the corrosion rate because the metals are passivated (Revie \& Uhlig, 2008). As can be seen in Figure 29, for metals

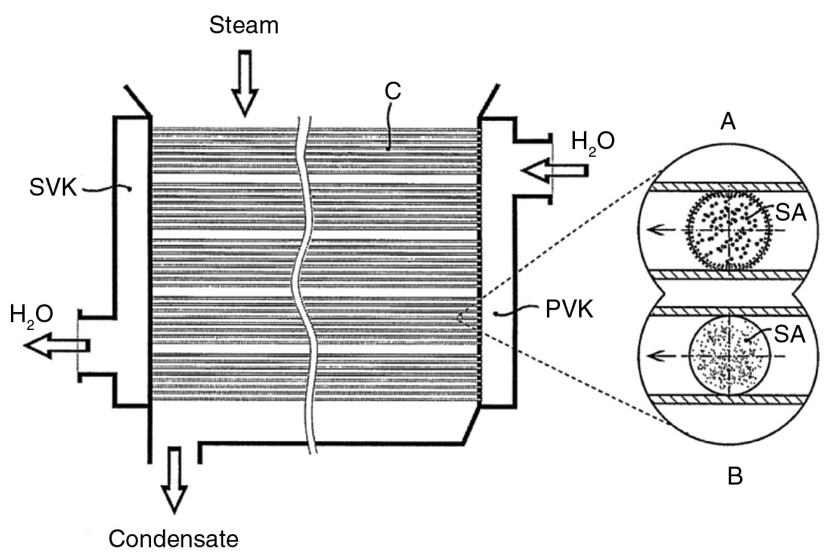

Figure 28: Cathodic protection of heat exchanger tubes with mobile sacrificial anodes (SA).

These balls can be made of a polymer with metallic elements (A) or can be completely metallic (B) (Ivusic, 2004). 


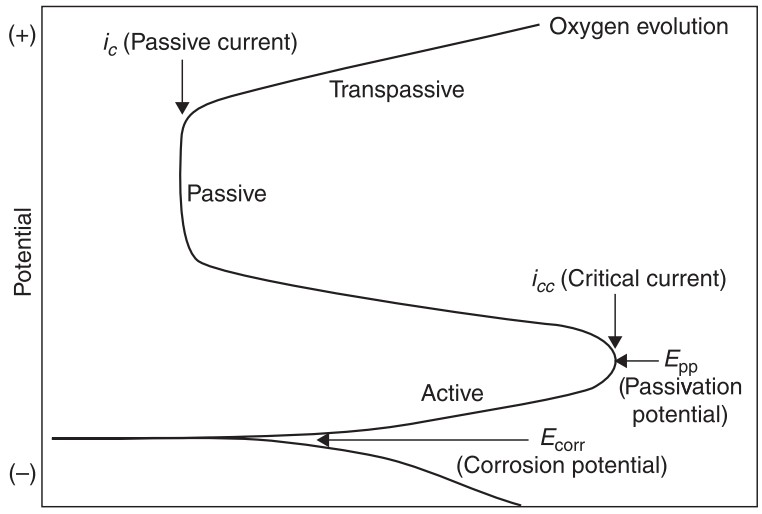

Log (current density)

Figure 29: Polarisation curve for a metal with an active-passive transition.

Reprinted from Roberge (2008), with permission from McGraw-Hill Education.

that exhibit an active-passive behaviour, an increase in potential first increases the corrosion rate (indicated on the figure by the current density), but then decreases with several orders of magnitude. In the transpassive region, the corrosion rate sharply increases again. Unlike cathodic protection, anodic protection can only be used with metals that have this active-passive transition in the specific environment of the heat exchanger.

An anodic protection system requires a power source, a potential controller, a cathode, and a reference electrode (Roberge, 2000). The cathode should be as large as possible. For a reduction of the electrical resistance of the circuit, multiple cathodes can be used in parallel. The reference electrode is required to carefully control the potential. This electrode should have a potential that is constant and should not be influenced by temperature. Failure of the reference electrode can cause a faulty operation of the system with large corrosion problems as a consequence.

The advantages of anodic protection are that, once the metal has passivated, only a small current is required. Moreover, the current gives a direct indication of the corrosion rate. However, it only reduces the corrosion rate but never entirely stops it, in contrast to cathodic protection. When the electrical supply stops, the metal can de-passivate and be subject to serious damage (Revie \& Uhlig, 2008). If this happens when the heat exchanger is expected to be protected, the consequences can be disastrous. Anodic protection can only be used in well-known and stable environments, as changes in the environment can chance the active-passive behaviour (Roberge, 2000).

One of the main applications of anodic protection is to prevent corrosion in heat exchangers and other equipment handling sulphuric acid (Roberge, 2000). The anodic corrosion protection of a sulphuric acid cooler is discussed in a paper by Paulekat et al. (1982). The acid, with concentrations up to $99 \%$ and temperatures up to $160^{\circ} \mathrm{C}$, flows through austenitic stainless-steel pipes. Without protection, this environment would cause severe damage to the metal. After performing laboratory studies to determine the passive range and the current densities for several conditions, the system was installed and the corrosion rates were reduced up to two orders of magnitude. According to the authors, the system can be used on complicated designs and, although it has a high investment cost (a power source, a controller, a cathode, and a reference electrode are required), the system can reduce the total cost because a cheaper material can be chosen and less shutdowns occur.

A lot of information on the use of anodic protection of heat exchangers is disclosed in patents. Patents discussing the anodic protection of shell-and-tube heat exchangers were assigned to McAlister (1987), Cameron (1996), and Sanz $(1986,1996)$. In all these documents, the corrosive fluid, e.g. sulphuric acid, flows over the tubes at the shell side. To protect the heat exchanger, both the shell and the tubes are connected to a cathode through an external power source. These cathodes are placed in the shell as long cylindrical objects, parallel to the tubes. This kind of set-up is shown in Figure 30. In this figure, the shell 10 , the cathode 15 , the power source 25 , and the two reference electrodes 20 and 30 are displayed. The tubes are not shown.

The patents by Bennett and Elliot $(1981,1982)$ also use anodic protection in heat exchangers. In their invention, however, the goal is to prevent biofouling and scaling of the tubes. The tubes are anodically polarised to a potential where they start evolving oxygen. This prevents organisms in seawater from attaching to the surface. This technique is similar to the patent by Inagaki et al. (2002), but there,

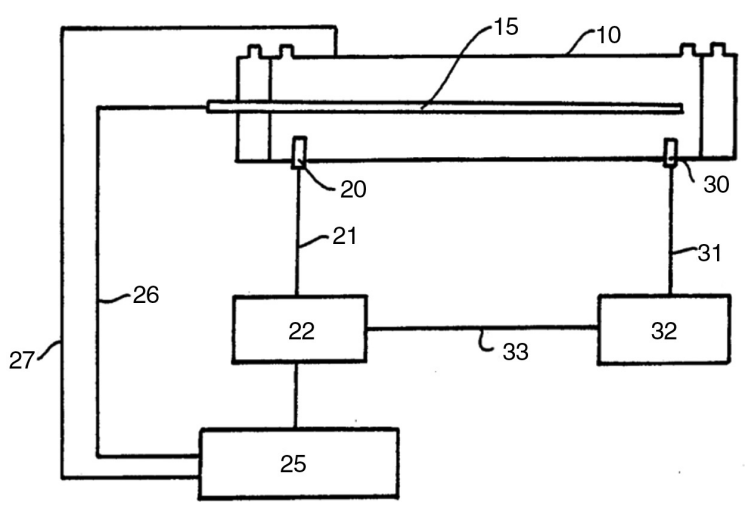

Figure 30: Anodic protection of a shell-and-tube heat exchanger (McAlister, 1987). 
the tubes were cathodically polarised and the tube sheet was used as anode.

Plate heat exchangers can be anodically protected as well, as discussed in the patents assigned to Anastasijevic et al. (2004), Karlsson and Berthagen (1989), and Carlson et al. (1986). For both patents by Anastasijevic et al. (2004) and Karlsson and Berthagen (1989), the cathodes are placed in the inlet and outlet channels. The reference electrode is placed in the outlet channel in the patent by Anastasijevic et al. (2004) and in a separate flow path, further away from the cathodes, in the patent by Karlsson and Berthagen (1989). Karlsson and Berthagen (1989) claimed that this secures the anodic protection in all parts of the heat exchanger. The invention in the patent by Carlson et al. (1986) is based on the patents assigned to Bennett and Elliot (1981, 1982), and serves again to prevent biofouling. Pairs of plates act either as cathode or anode. In the channel with the fouling fluid, e.g. seawater, oxygen is evolved from the anode, thus preventing the deposition of organisms on the plates. The corrosion protection and biofouling control of plate heat exchangers are illustrated in Figures 31 and 32, respectively. The power source 20 in Figure 31 is connected to the cathodes 16 and 17 in the inlet and outlet channel and to the plates 7 . The reference electrode 27 is also located in the outlet channel. In Figure 32, oxygen is evolved in the seawater channels 34 from the plates 12 connected to the positive pole of the power source.

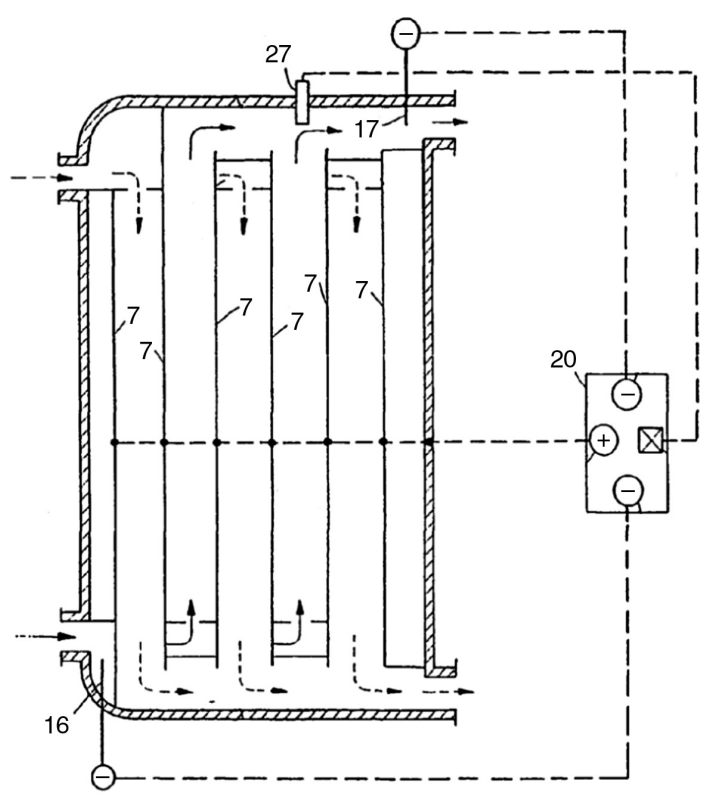

Figure 31: Anodic protection of a plate heat exchanger (Anastasijevic et al., 2004).

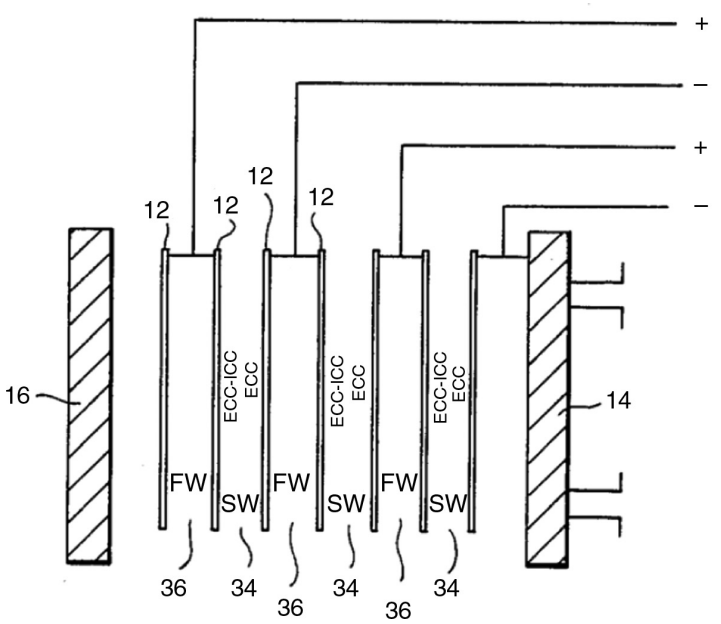

Figure 32: Anodic polarisation of plates to control biofouling in plate heat exchangers (Carlson et al., 1986).

\section{Conclusion}

In this paper, all main aspects about corrosion in heat exchangers were reviewed. The first part provided a discussion on the different types of corrosion occurring in heat exchangers, together with an overview of failure analyses where the respective corrosion processes were the main cause of failure. Next, the influence of heat transfer on corrosion and the influence of corrosion on the thermohydraulic performance of heat exchangers were discussed. Finally, several methods used for the prevention of corrosion were considered. The following observations and conclusions could be made:

1. Ample examples of heat exchangers failed by corrosion can be found, indicating the severity of the problem. Only a minority of the failures are caused by uniform corrosion. Localised forms, especially pitting and SCC, frequently occur. These are followed by crevice corrosion and MIC.

2. The corrosion rate is influenced by the heat transfer in different ways. The main factor is the temperature gradient that exists over the boundary layer near the wall. This causes differences in the solubility of elements in the fluid. Depending on the corrosive species and on whether the fluid is being heated or cooled, this gradient can increase or decrease the corrosion rate.

3. Corrosion has an adverse effect on the thermohydraulic performance of heat exchangers. The heat transfer rate will typically decrease. This is mainly attributed to the low thermal conductivity of the corrosion products, which can be several orders of magnitude 
smaller than that of the base metal. Furthermore, the corrosion products, which are usually more voluminous than the base metal, can obstruct the flow and increase the pressure drop.

4. The most important methods to prevent corrosion of heat exchangers are an adequate material selection with a combination of proper control of the environment. During the design, attention should be paid to avoiding crevices and sharp edges, and for demanding applications, special construction elements can be used (e.g. impingement plates in shell-and-tube heat exchangers or double-wall plate heat exchangers). Regarding the thermal design, it is important to have the highest heat transfer coefficient on the cold side as to reduce the temperature of the heat transfer surfaces.

5. Although cathodic and anodic protection have been proven to be effective in laboratory studies and several examples of the application of such systems in heat exchangers can be found in the patent literature, only a small amount of scientific literature on this topic exists. The results of the existing scientific research on these systems in heating or cooling applications are mostly positive. Some failure analyses exist, however, where improper use of cathodic protection is at the basis of the failure.

This paper illustrates that the presence of a corrosive environment, flow behaviour, high temperatures, and heat transfer over a surface make the corrosion of heat exchangers a specific problem. Nonetheless, failures occur in many different domains. Applications with seawater, geothermal brines, or in (petro)chemical plants are only some examples of industries that are regularly faced with these corrosion-related issues.

It is clear from the high number of failure analyses found in the recent literature that there is a need for a continued research on how to reduce the risk of corrosion in heat transfer applications. Compared to the amount of failures found, the number of publications on the influence of corrosion on the performance of heat exchangers and the effect of heat transfer on the corrosion process are scarce. Also regarding the prevention of corrosion, there still is room for improvement.

To solve the problem and increase the knowledge on the topic, new research could be done on several aspects. First of all, continued investigations on the development of corrosion-resistant materials for different environments are required. The separation of the metal from the solution by the application of a suitable coating is another option. The research on electrochemical techniques to reduce the corrosion rate (like cathodic or anodic protection) is still limited and should be expanded. An alternative approach might be to change the heat exchanger design so that corrosion can be tolerated or that corroded parts can be replaced easily.

\section{References}

Abouswa K, Elshawesh F, Elragei O, Elhood A. Corrosion investigation of $\mathrm{Cu}-\mathrm{Ni}$ tube desalination plant. Desalination 2007; 205: 140-146.

Abraham JG, Kain V, Dey GK. MIC failure of cupronickel condenser tube in fresh water application. Eng Fail Anal 2009; 16 : 934-943.

Al-Hashem A, Carew J, Al-Sayegh A. The sacrificial cathodic protection of UNS C71500 heat exchanger tubes in Arabian Gulf sea water. Technical report. Houston, TX: NACE International, 1997.

Allahkaram S, Zakersafaee P, Haghgoo S. Failure analysis of heat exchanger tubes of four gas coolers. Eng Fail Anal 2011; 18 : 1108-1114.

Anastasijevic N, Daum KH, Schalk W, Laibach S. Plate-type heat exchanger with anodic corrosion protection, 2004. Patent application: US 2004/0251005 A1.

AZoM. Titanium dioxide-titania $\left(\mathrm{TiO}_{2}\right)$. URL https://www.azom.com/ article.aspx?ArticleID=1179. Accessed 16 March, 2018.

Bennett JE, Elliot JE. Anodically polarized surface for biofouling and scale control, 1981. US Patent 4,256,556.

Bennett JE, Elliot JE. Anodically polarized surface for biofouling and scale control, 1982. US Patent 4,345,981.

Boffardi BP. Corrosion inhibitors in the water treatment industry. In: ASM handbook, vol. 13A, chapter Corrosion: fundamentals, testing, and protection. Materials Park, $\mathrm{OH}$ : ASM International, 2003: 891-906.

Callister WD, Rethwisch DG. Materials science and engineering, vol. 5. New York: John Wiley \& Sons, 2011.

Cameron GM. Anodis protection method and system, 1996. US Patent 5,513,694.

Carlson RC, DeRespiris DL, Sacco AR, Groszek DJ, Ivancic BM. Plate and frame heat exchanger assembly with anodic protection, 1986. US Patent 4,586,562.

Carter V. Metallic coatings for corrosion control. London: NewnesButterworths, 1977.

Cassagne T, Houlle P, Zuili D, Bluzat P, Corrieu JM, Larché N. Replacing titanium in sea water plate heat exchangers. In: CORROSION 2010. Houston, TX: NACE International, 2010.

Chandra K, Kain V, Dey G, Shetty P, Kishan R. Failure analysis of cupronickel evaporator tubes of a chilling plant. Eng Fail Anal 2010; 17: 587-593.

Chang J, You S. Enhanced boiling heat transfer from microporous surfaces: effects of a coating composition and method. Int J Heat Mass Transfer 1997; 40: 4449-4460.

Cincera S, Barella S, Bellogini M, Bresciani E. De-nickelification of 70/30 cupronickel tubing in a cooling heat exchanger. J Fail Anal Prev 2012; 12: 300-304.

Collier J. Reliability problems of heat transfer equipment. Heat Transf Eng 1983; 4: 51-62. 
Collins JA. Effect of design, fabrication and installation on the performance of stainless steel equipment. Corrosion 1955; 11: 27-34.

Corleto CR, Argade GR. Failure analysis of dissimilar weld in heat exchanger. Case Studies Eng Fail Anal 2017; 9: 27-34.

Corte J, Rebello J, Areiza M, Tavares S, Araujo M. Failure analysis of AISI 321 tubes of heat exchanger. Eng Fail Anal 2015; 56: 170-176.

Crum J, Hazeldine P, Shoemaker L, Peschel J. Evaluation of materials for seawater plate heat exchanger applications. In: CORROSION 2007. Houston, TX: NACE International, 2007.

Das A, Kilty H, Marto P, Andeen G, Kumar A. The use of an organic self-assembled monolayer coating to promote dropwise condensation of steam on horizontal tubes. J Heat Transf 2000; 122: $278-286$

Davis JR. Corrosion: Understanding the basics. Materials Park, $\mathrm{OH}$ : ASM International, 2000.

Deen K, Virk M, Haque C, Ahmad R, Khan I. Failure investigation of heat exchanger plates due to pitting corrosion. Eng Fail Anal 2010; 17: 886-893.

Deivasigamani S, Preiser HS. Heat exchanger including selectively activated cathodic protection useful in sulfide contaminated environments, 2013. US Patent 8,511,370.

Depover T, Verbeken K. The detrimental effect of hydrogen at dislocations on the hydrogen embrittlement susceptibility of Fe-C-X alloys: an experimental proof of the HELP mechanism. Int J Hydrogen Energy 2018; 43: 3050-3061.

Dexter S. Microbiologically influenced corrosion. In: ASM handbook, vol. 13A, chapter Corrosion: Fundamentals, Testing, and Protection. Materials Park, OH: ASM International, 2003: 398-416.

Edwards JE. Design and rating shell and tube heat exchangers. Teesside, UK: P \& I Design Ltd., 2008.

Edwards R. Aqueous corrosion of steel, 2013.

Eich G. Erosion corrosion on oil coolers for navy ships. J Fail Anal Prev 2012; 12: 490-493.

El-Amoush AS, Zamil A, Jaber D, Ismail N. Stress corrosion cracking of the pre-immersed tin brass heat exchanger tube in an ammoniacal solution. Mater Des (1980-2015) 2014; 56: 842-847.

Electric Power Research Institute. Cost of corrosion in the electric power industry. EPRI 1004662, 2001.

Elliot P. Design details to minimize corrosion. ASM Handb 1987; 13: 338-343.

Fedrizzi L, Andreatta F, Paussa L, Deflorian F, Maschio S. Heat exchangers corrosion protection by using organic coatings. Progr Org Coat 2008; 63: 299-306.

Francis R. Hot spot corrosion in condenser tubes: its causes and prevention. Br Corros J 1987; 22: 199-201.

Fulford J, Schutz R, Lisenbey R. Characterization of titanium condenser tube hydriding at two Florida power and light company plants. In: Joint ASME/IEEE Power Generation Conference, Miami Beach, Florida, 1987.

Ghayad IM, Hamid ZA, Gomaa N. A case study, corrosion failure of tube heat exchanger. J Metallurg Eng 2015; 4: 57-61.

Graff M, Mazej M, Ogorevc T. Cathodic protection of a heat exchanger, 2017. Patent WO 2017/072177 A1.

Green M. Corrosion under heat transfer: service failures and laboratory testing. Br Corros J 1967; 2: 153-158.

Groysman A. Corrosion problems and solutions in oil refining and petrochemical industry. Dordrecht: Springer, 2017.
Guedes Soares C, Garbatov Y, Zayed A. Effect of environmental factors on steel plate corrosion under marine immersion conditions. Corros Eng Sci Technol 2011; 46: 524-541.

Guo C, Han C, Tang Y, Zuo Y, Lin S. Failure analysis of welded 0Cr13Al tube bundle in a heat exchanger. Eng Fail Anal 2011; 18: 890-894.

Health and Safety Executive. Catastrophic failure of shell and tube production cooler, 2006. URL: http://www.hse.gov.uk/ offshore/alerts/sa_01_06.htm. Accessed 23 April, 2018.

Hong K, Webb RL. Wetting coatings for dehumidifying heat exchangers. HVAC\&R Res 2000; 6: 229-242.

Huttunen-Saarivirta E, Honkanen M, Lepistö T, Kuokkala VT, Koivisto L, Berg CG. Microbiologically influenced corrosion (MIC) in stainless steel heat exchanger. Appl Surf Sci 2012; 258: 6512-6526.

Ifezue D, Tobins F. Corrosion failure of aluminum heat exchanger tubes. J Fail Anal Prev 2015; 15: 541-547.

Inagaki S, Sakurada S, Nakashima S, Ooba T. Antifouling system for structure exposed to seawater and heat exchanger, 2002. US Patent 6,579,429.

Ivusic V. Cathodic protection of heat exchanger tubes by means of mobile sacrificial anodes, 2004. Patent WO 2004/104270 A1.

Jennings P. A new look at the explosion that caused the Sultana disaster. The Hartford Steam Boiler Inspection and Insurance Company, 2015.

Jong-Soon K, Tae-Ho K, In-Kwan K. Surface treatment to improve corrosion resistance of Al plate heat exchangers. Trans Nonferrous Metals Soc China 2009; 19: s28-s31.

Julian R, Lichti K, Mroczek E, Mountain B. Heavy metal scaling and corrosion in a geothermal heat exchanger. In: Proceedings World Geothermal Congress 2015, 2015.

Kakaç S, Liu H, Pramuanjaroenkij A. Heat exchangers: selection, rating, and thermal design. Boca Raton, FL: CRC Press, 2012.

Karlsson B, Berthagen L. Corrosion protection for heat exchangers, 1989. US Patent 4,800,007.

Kaul R, Muralidharan N, Jayakumar T, Kasiviswanathan K, Raj B, Dayal R, Raju V, Gnanamoorthy J, Pattu S. Failure analysis of carbonate reboiler heat exchangers. Eng Fail Anal 1995; 2: 165-174.

Khodamorad S, Alinezhad N, Fatmehsari DH, Ghahtan K. Stress corrosion cracking in type 316 plates of a heat exchanger. Case Studies Eng Fail Anal 2016; 5: 59-66.

Klein U, Zunkel A, Eberle A. Breakdown of heat exchangers due to erosion corrosion and fretting caused by inappropriate operating conditions. Eng Fail Anal 2014; 43: 271-280.

Klenowicz Z, Darowicki K, Krakowiak S, Krakowiak A. Corrosionerosion damage of heat exchanger tubes by desalted crude oil flowing at shell side. Mater Corros 2003; 54: 181-187.

Knezevic M, Jahedi M, Korkolis YP, Beyerlein IJ. Material-based design of the extrusion of bimetallic tubes. Comput Mater Sci 2014; 95: 63-73.

Koch GH, Brongers MP, Thompson NG, Virmani YP, Payer JH. Corrosion cost and preventive strategies in the United States. Technical report, 2002.

Kuppan T. Heat exchanger design handbook. New York: Marcel Dekker, Inc., 2000.

Kuznicka B. Erosion-corrosion of heat exchanger tubes. Eng Fail Anal 2009; 16: 2382-2387.

LaQue F. The corrosion handbook. New York: John Wiley \& Sons, Inc., 1948. 
Li YD, Xu N, Wu XF, Guo WM, Shi JB, Zang QS. Failure analysis of the condenser brass tube in $150 \mathrm{MW}$ thermal power units. Eng Fail Anal 2013; 33: 75-82.

Marsh P. Process-safety case studies - catastrophic failures of heat exchangers, 2016. URL http://www.engineersjournal. ie/2016/11/01/process-safety-failures-heat-exchangers/. Accessed 12 April, 2018.

Maylor J. Heat transfer and corrosion of high-nickel alloys. Br Corros J 1967; 2: 168-171.

McAlister DR. Control of anodic passivation systems, 1987. US Patent 4,689,127.

Moore P, Smith S. Practical applications of corrosion-testing apparatus under heat-transfer conditions. Br Corros J 1967; 2: 143-149.

Mousavian RT, Hajjari E, Ghasemi D, Manesh MK, Ranjbar K. Failure analysis of a shell and tube oil cooler. Eng Fail Anal 2011; 18: 202-211.

NACE International. International measures of prevention, application, and economics of corrosion technologies study. Houston, TX: NACE International, 2016.

Noboru K, Yuuj N, Katsunari O, Katsuaki T, Shuichi I, Sunao W. Cathodic protection apparatus in systems for the circulation of corrosive liquids, 1989. European Patent EP 0324440 A1.

Otegui JL, Fazzini PG. Failure analysis of tube-tubesheet welds in cracked gas heat exchangers. Eng Fail Anal 2004; 11: 903-913.

Pakhomov V, Parshin A. Corrosion protection of heat-exchanger equipment at the design stage. Chem Petrol Eng 1993; 29: 181-187.

Parrott R. Potential hazards from undetected corrosion in complex equipment: a case study of the destructive separation of an offshore heat exchanger. Eng Fail Anal 2014; 44: 424-440.

Paulekat F, Graefen H, Kuron D. Anodic corrosion protection of sulphuric acid plants with regard to the recovery of heat. Mater Corros 1982; 33: 254-262.

Powell C, Michels H. Copper-nickel for seawater corrosion resistance and antifouling: a state of the art review. Rem 2000; 90: 10.

Qiankun Z, Yafei S, Sixian R, Huifeng L, Xingjiang Z. Corrosion failure analysis on heat exchanger pipes. J Fail Anal Prev 2017; 17: 349-353.

Qu S, Yao G, Tian J, Zhang Z. Failure analysis of the brass tubes in a lubricating oil cooler. Eng Fail Anal 2011; 18: 2232-2239.

Ranjbar K. Effect of flow induced corrosion and erosion on failure of a tubular heat exchanger. Mater Des 2010; 31: 613-619.

Rao T, Nair K. Microbiologically influenced stress corrosion cracking failure of admiralty brass condenser tubes in a nuclear power plant cooled by freshwater. Corros Sci 1998; 40: 1821-1836.

Ravindranath K, Tanoli N, Gopal H. Failure investigation of brass heat exchanger tube. Eng Fail Anal 2012; 26: 332-336.

Reitz W. SO heat exchanger failure. Pract Fail Anal 2002; 2: 45-49.

Revie RW, Uhlig HH. Corrosion and corrosion control: an introduction to corrosion science and engineering. New York: John Wiley \& Sons, Inc., 2008.

Rizk TY, Al-Nabulsi KM, Cho MH. Microbially induced rupture of a heat exchanger shell. Eng Fail Anal 2017; 76: 1-9.

Roberge PR. Handbook of corrosion engineering. New York: McGraw-Hill, 2000.

Roberge PR. Corrosion engineering: principles and practice. New York: McGraw-Hill, 2008.

Ross T. Corrosion and heat transfer - a review. Br Corros J 1967; 2: 131-142.
Sanders S, Iwand H. Failure analysis of ethanol vaporizer heat exchanger tubes. J Fail Anal Prev 2013; 13: 328-332.

Sanz D. Anodic protection system and method, 1986. US Patent $4,588,022$.

Sanz D. Anodically protected heat exchanger, 1996. US Patent $5,515,913$.

Shackelford JF, Alexander W. Thermal properties of materials. Materials science and engineering handbook, vol. 5. Boca Raton, FL: CRC Press, 2001.

Shahrani S, Al-Subai S. Failure analysis of heat exchanger tubes. J Fail Anal Prev 2014; 14: 790-800.

Shalaby H. Failure investigation of Muntz tubesheet and Ti tubes of surface condenser. Eng Fail Anal 2006; 13: 780-788.

Sharma P. Microbiological-influenced corrosion failure of a heat exchanger tube of a fertilizer plant. J Fail Anal Prev 2014; 14: 314-317.

Silverman D. Aqueous corrosion. In: ASM handbook, vol. 13A, chapter Corrosion: fundamentals, testing, and protection. Materials Park, OH: ASM International, 2003: 190-195.

Song WM, Yang GR, Hao Y, Zhang YF. The corrosion failure analysis of plate pipe for plate heat exchanger. In: Advanced materials research, vol. 750. Switzerland: Trans Tech Publications, 2013: 2252-2257.

Strangman TE. Thermal barrier coatings for turbine airfoils. Thin Solid Films 1985; 127: 93-106.

Stumm W, Morgan JJ. Aquatic chemistry: chemical equilibria and rates in natural waters, vol. 126. New York: John Wiley \& Sons, 2012.

Suzuki H, Sasaki T, Nagasawa M, Takahashi N. Aluminum alloy fin material for heat exchanger and method of production of same and method of production of heat exchanger by brazing fin material, 2015. US Patent US2015/0107731 A1.

Syrett BC, Gorman JA. Cost of corrosion in the electric power industry: an update. Mater Perform 2003; 42: 32-38.

Tawancy H. Failure of hydrocracker heat exchanger tubes in an oil refinery by polythionic acid-stress corrosion cracking. Eng Fail Anal 2009; 16: 2091-2097.

Terai S, Tanabe Z, Fukui T. Heat exchanger core having fin members serving as sacrificial anodes, 1980. US Patent 4,203,490.

The Engineering ToolBox. Thermal conductivity of common materials and gases, 2017. URL http://www.engineeringtoolbox.com/ thermal-conductivity-d_429.html. Accessed 16 March, 2018.

Todd B. The corrosion of materials in desalination plants. Desalination 1967; 3: 106-117.

Traubert TD, Jur TA. Metallurgical analysis to evaluate cracking in a 316 L grade stainless steel spiral heat exchanger. J Fail Anal Prev 2012; 12: 198-203.

Tsai WT, Ju CP, Wen YN, Lee JT. Hydride formation during the cathodic polarization of titanium in artificial sea water. Surf Coat Technol 1987; 31: 401-408.

Turissini R, Bruno T, Dahlberg E, Setterlund R. Corrosion failures in plate heat exchangers. Technical report. Houston, TX: NACE International, 1997.

Tuthill AH. The right metal for heat exchanger tubes. Chem Eng 1990; 97: 120.

U.S. Chemical Safety and Hazard Investigation Board. Catastrophic rupture of heat exchanger. U.S. Chemical Safety and Hazard Investigation Board, 2010.

Veldkamp J, Goldberg T, Bressers P, Wilschut F. TNO report: corrosion in Dutch geothermal systems. Energy/Geological Survey of the Netherlands, 2016. 
Walker G. Industrial heat exchangers: a basic guide. Washington: Hemisphere Pub. Corp., 1990.

Wang CC, Chang CT. Heat and mass transfer for plate fin-and-tube heat exchangers, with and without hydrophilic coating. Int J Heat Mass Transf 1998; 41: 3109-3120.

Wang L, Sundén B, Manglik RM. Plate heat exchangers: design, applications and performance, vol. 11. Southampton, UK: Wit Press, 2007.

Wassilkowska A, Skowronek T, Rybicki S. Microstructure investigation of premature corroded heat exchanger plates. Mater Test 2016; 58: 218-223.

Weast RC. CRC handbook of chemistry and physics, 61st ed, 1980-1981. Cleveland, OH: Chemical Rubber, 1981.

Welty JR, Wicks CE, Rorrer G, Wilson RE. Fundamentals of momentum, heat, and mass transfer. New York: John Wiley \& Sons, 2009.

Wigen SM, Osvoll H, Gartland PO, Huang W. Efficient cathodic protection of stainless steel small bore tubing. In: CORROSION 2007. Houston, TX: NACE International, 2007.

Xie J, Yazdanfar K, Anning G, Rockwell T, Ahmed A. Corrosion of a vertical shell and tube heat exchanger. In: CORROSION 2015. Houston, TX: NACE International, 2015.

Xu S, Wang C, Wang W. Failure analysis of stress corrosion cracking in heat exchanger tubes during start-up operation. Eng Fail Anal 2015; 51: 1-8.

Yager WM. The sultana disaster. Tenn Hist Q 1976; 35: 306-325.

Yang ZG, Gong Y, Yuan JZ. Failure analysis of leakage on titanium tubes within heat exchangers in a nuclear power plant. Part I: Electrochemical corrosion. Mater Corros 2012; 63: 7-17.

Zhao Y, Qi Z, Wang Q, Chen J, Shen J. Effect of corrosion on performance of fin-and-tube heat exchangers with different fin materials. Exp Thermal Fluid Sci 2012; 37 : 98-103.

Zheng Y, Liu G, Zhang Y, Hu H, Song Q. Corrosion failure analysis of a condenser on the top of benzene tower in styrene unit. J Fail Anal Prev 2014; 14: 286-295.

\section{Bionotes}

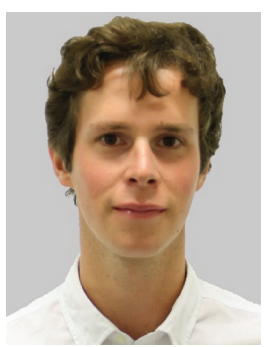

\section{Willem Faes}

Department of Flow, Heat and Combustion

Mechanics, Ghent University, Ghent,

Belgium; and Flemish Institute of

Technological Research (VITO), Mol,

Belgium,

willem.faes@ugent.be

Willem Faes obtained his MSc in mechanical engineering at Ghent University in 2016. The title of his master's thesis was "Useful energy transfer in air-to-air heat recovery units in low energy buildings". Afterwards, he started his PhD in the same university at the Department of Flow, Heat and Combustion Mechanics, together with the Flemish Institute of Technological Research (VITO). His research is focussed on the design of heat exchangers in (corrosive) geothermal environments.

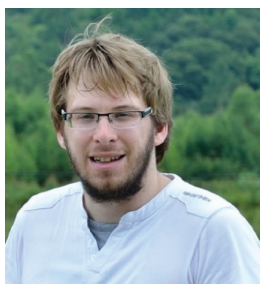

Steven Lecompte

Department of Flow, Heat and Combustion

Mechanics, Ghent University, Ghent,

Belgium
Steven Lecompte is a research fellow at the Department of Flow, Heat and Combustion Mechanics, Ghent University, Belgium. He obtained his master's and PhD degrees in electromechanical engineering at Ghent University in 2012 and 2016, respectively. His PhD thesis was titled "Performance evaluation of organic Rankine cycle architectures: Application to waste heat valorisation”. For his master's thesis, he received the ArcelorMittal prize. His research is on thermomechanical energy conversion including thermo-economic optimisation of thermal systems and multi-phase processes.

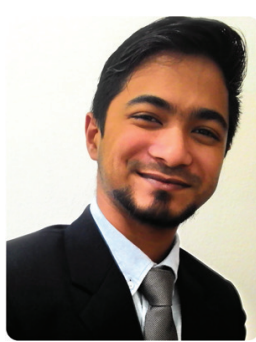

Zaaquib Yunus Ahmed

Department of Flow, Heat and Combustion Mechanics, Ghent University, Ghent, Belgium

Zaaquib Yunus Ahmed obtained his master's degree in computational mechanics from the University of Stuttgart and UPC Barcelona. The title of his master's thesis was "Numerical simulation of tip leakage flows in a compressor cascade". He later started his PhD at the University of Ghent on "3-D thermal modelling of a slab in a continuous walking beam furnace", in cooperation with ArcelorMittal, Belgium. The focus of his research is to model the heat transfer into the slabs in a furnace, taking into account different thermodynamic processes that affect the slab heat transfer.

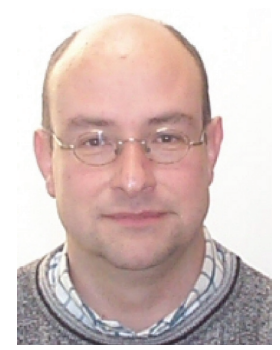

\section{Johan Van Bael}

Flemish Institute of Technological Research (VITO), Mol, Belgium; and EnergyVille, Thor Park, Genk, Belgium

Johan Van Bael has a master's degree in electromechanical engineering. As a project manager since 1995, he worked on several regional, national, and European projects both for the government and for the industry on cooling and heating systems, conversion systems [organic Rankine cycle (ORC) and heat pumps], co-generation, thermal energy storage, and renewable energy sources. He is currently the project manager for the research group on conversion systems (heat pumps and ORC), thermal energy storage. Johan is expert in different European projects like FP7 Merits, FP7 E-Hub, H2020 Story, H2020 MATChING, and H2020 FHP, and different KIC EIT projects like KIC Energy Storage, KIC Estore, and KIC Flex². He is also an inventor of several VITO patents. 


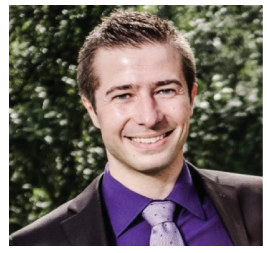

\section{Robbe Salenbien}

Flemish Institute of Technological Research (VITO), Mol, Belgium; and EnergyVille, Thor Park, Genk, Belgium

Robbe Salenbien obtained his MSc (cum laude) and PhD in physics at the KU Leuven, in 2007 and 2012, respectively. He was involved in photoacoustic and photothermal studies of ultrathin structures and viscoelastic materials. In 2012, he joined the Flemish Institute of Technological Research (VITO) as a researcher in energy technology, focussing on smart district applications such as optimal technology integration. He is engaged in different national and international relevant research projects, e.g. FP7 Resilient, IWT-VIS Smart Geotherm, and EFRO SALK GeoWatt. Currently, he is active as domain responsible for the thermal energy systems research group in EnergyVille.

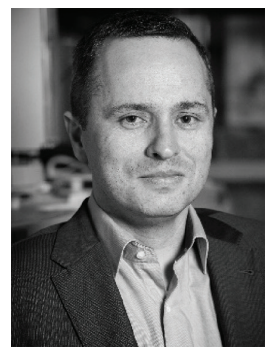

\section{Kim Verbeken}

Department of Materials, Textiles and Chemical Engineering, Ghent University, Ghent, Belgium

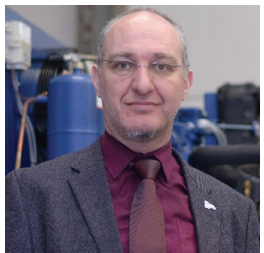

\section{Michel De Paepe}

Department of Flow, Heat and Combustion Mechanics, Ghent University, Ghent, Belgium; and Flanders Make, Core Lab UGent-EEDT, www.flandersmake.be, Lommel, Belgium

Michel De Paepe ( $\left.{ }^{\circ} 1972\right)$ is professor of thermodynamics and heat transfer and is currently the head of the research group Applied Thermodynamics and Heat Transfer at the Faculty of Engineering and Architecture of Ghent University. Research in this group focuses on thermodynamics of new energy systems, performance of HVAC (heating, ventilation, and air conditioning) systems and energy in buildings, and complex heat transfer phenomena in industrial applications, as in compact heat exchangers, combustion engines, refrigerant two-phase flow, and electronics cooling. Michel De Paepe was supervisor/promotor of $18 \mathrm{PhDs}$ defended at Ghent University. Michel De Paepe is (co)author of 117 papers published in international peer-reviewed journals and $>350$ conference papers.

Kim Verbeken, after obtaining his PhD from Ghent University in 2004, obtained a postdoctoral fellowship from the Research Foundation-Flanders (FWO). As a postdoc, he also worked for 1 year at the Max-Planck Institute for Iron Research (Düsseldorf). In 2010, Kim Verbeken became research professor at Ghent University and initiated the research group Sustainable Materials Science (https://www.ugent.be/ea/match/sms/en), which is embedded in the Department of Materials, Textiles and Chemical Engineering (MaTCh). His research focuses on three topics:

- The study of the interaction of materials with hydrogen;

- The study of degradation of materials by interaction with their environment;

- The study of high-temperature metallurgical processes by both a modelling and experimental approach. 